\title{
International Economic Activities and the Demand for Skilled Labor: Evidence from Brazil and China
}

\author{
Pablo Fajnzylber \\ The World Bank
}

\author{
Ana M. Fernandes \\ The World Bank
}

September 27, 2004

\begin{abstract}
Increases in international economic integration can lead to greater specialization according to comparative advantage, but also to the diffusion of skill-biased technologies. In developing countries characterized by relative abundance of unskilled labor, these factors can have opposite effects on the relative demand for skilled labor. This paper investigates the impact of the use of imported inputs, exports and foreign direct investment on the demand for skilled workers of Brazilian and Chinese manufacturing plants. We find that while in Brazil increased levels of international integration are associated with an increased demand for skilled labor, the opposite is true in China.
\end{abstract}

JEL Classification Numbers: F02, F16, J23, J31, O33.

Keywords: technology diffusion, labor demand, trade and labor market interactions, foreign direct investment, exports.

\footnotetext{
*This paper has benefited from the suggestions of participants at the Second Industrial Development Conference (World Bank, Washington DC). The findings expressed in this paper are those of the authors and do not necessarily represent the views of the World Bank. Please address correspondence to Ana M. Fernandes, The World Bank, 1818 H Street, NW, Washington DC 20433. Phone: 202-473-3983. Fax: 202-522-3518. E-mail: afernandes@worldbank.org.
} 


\section{Introduction}

Among the hypotheses that have been proposed for explaining the increase in earnings differentials between skilled and unskilled workers observed in the United States during the 1980s, two have received outmost attention: the increase in trade with developing countries and skill-biased technological change. The first hypothesis postulates that during this period industrialized countries witnessed considerable increases in imports of unskilled-labor-intensive manufacturing products from developing countries which were liberalizing their trade regimes and facilitating foreign direct investment (FDI). ${ }^{1}$ The second hypothesis relates the increase in the demand for skilled workers to the intensification of the use of computers and related technologies that are relative complements to skilled labor. ${ }^{2}$

From the point of view of developing countries, the hypothesis that globalization has caused an increase in specialization according to comparative advantage should lead to an effect that is opposite to that observed in industrialized countries. Indeed, according to traditional trade theory, in developing countries a greater participation in international markets should be associated with the exploitation of comparative advantage in goods that are intensive in unskilled labor. This should cause a shift in demand towards this type of workers, and lead to a reduction in the wage differential with respect to their skilled counterparts. However, in the context of the second hypothesis highlighted above, the same international economic activities that are often associated with the exploitation of comparative advantage - the use of imported inputs, exports and FDI - could also act as channels for the international diffusion of skill-biased technologies developed in industrialized countries, which in principle could diminish or even compensate for the shifts in labor demand caused by increased specialization. Thus, while in industrialized countries the labor demand effects of greater international integration and those of skill-biased

1 See Wood (1994).

2 See Berman et al. (1994) and Autor et al. (1998). 
technological change can be safely assumed to reinforce each other, in developing countries both factors probably operate in opposite directions and empirical evidence is crucial to determine which tends to prevail. This paper provides new evidence on that question, by estimating the net effect of the use of imported inputs, exports and FDI on the relative demand for skilled workers, using recently collected manufacturing plant-level data from Brazil and China, two developing countries which have experienced significant increases in their degree of international integration.

Previous empirical work on the U.S. and other OECD countries has generally found skilledbiased technological change to be more important than trade as the main factor underlying the aforementioned labor demand shifts. Thus, only a small share of the observed changes in the demand for skilled labor can be attributed to a reallocation of production towards skill-intensive sectors - as the trade hypothesis would predict. Rather, it appears that most of the shift away from unskilled labor has taken place within narrowly defined industries, a result that is consistent with the hypothesis of skill-biased technical change. Moreover, studies using industry-level and plant-level data have found a direct link between the relative demand for skilled workers and investments in the adoption of computers or in research and development (R\&D). ${ }^{3}$ However, these studies have been less successful in uncovering the hypothesized effects of exports, imports and foreign investment flows on the demand for skilled labor. ${ }^{4}$

The evidence for developing countries is more scarce. In Mexico, the relative wages of skilled workers increased dramatically after the country liberalized its trade regime and relaxed restrictions on FDI in the early 1980s. Feenstra and Hanson (1997) show that the states and 3 See Berman et al. (1994), Doms et al. (1997), Dunne et al. (1997), Autor et al. (1998), Machin and Van Reenen (1998), and Haskel and Heden (1999).

4 For U.S. industries, some conflicting evidence is obtained. Slaughter (2000) and Bloningen and Slaughter (2001) find no important effects of, respectively, outward and inward FDI on the demand for skilled labor. Feenstra and Hanson (1996a) encounter a significant link between outsourcing (encompassing imports and contract work overseas) and the demand for skilled labor but Autor et al. (1998) obtain non-significant effects of imports and outsourcing and positive effects of exports on skill upgrading. 
industries which received more FDI exhibit a greater demand for skilled labor, a finding that they interpret as consistent with a model in which production outsourcing from an industrialized to a developing country raises the demand for skilled labor in both countries. ${ }^{5}$ Using plant-level data for the 1980s, Harrison and Hanson (1999) find that Mexican exporters and foreign-owned plants tend to employ a higher share of skilled workers, and so do plants that use more imported inputs and machinery. Pavcnik (2003) analyses panel data on Chilean manufacturing plants during the 1980s and finds that the use of imported materials, patented technology and foreign technical assistance appear to be unrelated to the demand for skilled labor in fixed effects and timedifferenced regressions. However, she reports positive effects of those three variables on skilled demand when using the cross-sectional variation in the data, which she interprets as reflecting unobserved plant heterogeneity driven, for example, by different degrees of managerial ability which affect both the adoption of foreign technology and the demand for skilled labor. ${ }^{6}$

This paper obtains new plant-level evidence from Brazil and China on the effect of international economic activities on the demand for skilled labor. As Harrison and Hanson (1999), we focus on the cross-sectional variation in the demand for skilled workers, and provide separate estimates on the effects of the use of imported inputs, exports and FDI on relative wages and relative employment. ${ }^{7}$ In order to account for the unobserved effects of managerial abil-

5 In the model proposed by Feenstra and Hanson (1996b), a single final good is produced with a continuum of intermediate inputs, which are traded between two countries, "North" and "South", with relative abundance of skilled and unskilled labor, respectively. The North specializes in inputs that are relatively intensive in skilled labor while the reverse is true for the South. A flow of capital from North to South leads to a shift of production activities to the South. Those activities are relatively intensive in unskilled labor by Northern standards, but they use more skilled labor than other inputs previously produced in the South, so that the relative wage of skilled labor increases in both countries.

${ }_{6}$ Gorg and Strobl (2001) use panel data on Ghanaian manufacturing plants to estimate the effect of exports and the use of imported machinery on the demand for skilled workers. They find that the latter is unrelated to exports, but positively linked to the use of imported machinery that was purchased for the purpose of technological progress.

7 Note that Harrison and Hanson (1999) use a panel dataset of Mexican manufacturing plants but most of their relative wage and relative employment regressions are estimated by OLS in levels. The only exception is a specification including only trade policy variables (tariffs and import licenses without any other controls) that is also estimated in differences. The justification for their approach is "the very little time series variation in many of the other independent variables" (p. 146). 
ity highlighted by Pavcnik (2003), we control for the managers' level of education, as well as for the presence of research and development (R\&D) activities and the introduction of new product lines. Furthermore, we show that our results are robust to a series of tests, including instrumental variables estimation, and estimation that allows for potentially different effects of international activities on plants pertaining to industries with revealed comparative advantage, and on private and state-owned plants (in the case of China).

Intermediate inputs are thought to act as a channel for the international diffusion of technology, provided that they embody state-of-the-art technologies not available domestically. ${ }^{8}$ Moreover, in their contacts with foreign suppliers importers may gain access to tacit, non-codified forms of knowledge, which are not transferable by means of market transactions. ${ }^{9}$ However, as argued above, one could also expect that within a given industry, those firms that make a greater use of imported inputs also choose to concentrate in the stages of the production process in which the country has comparative advantage. For instance, firms located in export-processing zones tend to import skill-intensive intermediate inputs and concentrate on unskilled-labor-intensive assembly operations.

The second international activity on which we focus is exporting. As in the case of importers, one can also argue that in a country with relative abundance of unskilled labor, within a given industry, exporters are more likely to "play to their strengths" and thus specialize in goods or stages of the production process that make a more intensive use of unskilled labor. On the other hand, exporters may be pressured by their foreign clients to produce according to quality standards that are higher than those prevailing in the domestic market, and they may also gain

8 See, for instance, the models of trade and endogenous growth in Grossman and Helpman (1991).

9 Keller (2004) notes that although the use of imported inputs may give rise to international spillovers associated with the fact that they cost less than their opportunity costs - including the R\&D cost of development - only the manufactured outcome of the technology, and not the technology as such, becomes available in the importing country, which makes this a "weak form of technology diffusion". The spillovers should be greater for imports from countries with larger R\&D stocks, which has been to some extent confirmed in empirical studies (e.g., Coe et al., 1997; Xu and Wang, 1999; and Lumenga-Neso et al., 2001). 
access to tacit information or even proprietary knowledge provided by their clients in order to help them meet those standards. ${ }^{10}$ Thus, exporting may also act as a channel for international technology diffusion and, to the extent that the absorbed technology is biased towards skilled labor, firms engaging in exporting activities could exhibit a greater demand for skilled workers, provided that this effect is not compensated by a greater degree of specialization according to comparative advantage.

In the case of FDI, the third activity which we consider, international technology diffusion can be expected to take place primarily through the sharing of firm-specific technology among multinational parents and subsidiaries. ${ }^{11}$ In fact, the existence of knowledge-based firm-specific assets and the intrinsic difficulties associated with their market-mediated transfer - for instance through technology licensing - are factors that have been featured prominently in theories that attempt to explain the very existence of multinational enterprises. ${ }^{12} \mathrm{~A}$ third factor that is often mentioned in order to explain the occurrence of FDI is the existence of location advantages in the host country. These advantages can be of two types: on the one hand, high transport costs or tariff barriers are normally linked to the use of "horizontal" FDI as a substitute for exports, as means for reaching the markets of sufficiently large countries. On the other hand, when factor prices differ across countries, location advantages may also be related to the relatively low costs of unskilled labor or other factors of production, giving rise to the so-called "vertical" FDI. ${ }^{13}$ As argued by Keller (2004), the extent of technology transfer to the host country is probably smaller in the latter type of FDI, which in our developing countries' context would imply a smaller impact on the demand for skilled labor. However, as argued by Feenstra and 10See Clerides et al. (1998), Hallward-Driemeier et al. (2002), and Keller (2004).

${ }^{11}$ It is worth noting that although FDI may lead to technology spillovers that benefit domestic firms and may thus affect their demand for skilled labor, this paper focuses only on direct effects of FDI and does not estimate spillover effects.

12See Markusen (1995).

13See Slaughter (2002). 
Hanson (1996b), it is also possible that while the activities transferred through vertical FDI are unskilled-labor-intensive in the country where the headquarters are located, the affiliates' use of skilled labor is still higher than that of their domestic counterparts in the host country.

As mentioned above, in order to account for the effects of unobserved managerial ability, which could affect both the decision to engage in international activities and the plants' demand for skilled labor, we employ variables that measure the managers' level of education and proxies for the plants' learning or absorptive capacity. As argued by Keller (1996), the lack of a minimum local critical mass of absorptive capacity may explain why some countries that have become outward-oriented have gained less than others in terms of access to international technology flows. The absorptive capacity of firms can be described as their "ability to identify, assimilate and exploit knowledge from the environment" (Cohen and Levinthal, 1989, p. 569). It encompasses both the ability to imitate new process or product innovations, and the capacity to use outside knowledge as the basis for internal innovative activities. The development of absorptive capacity, Cohen and Levinthal argue, is one of the motivations for firms to invest in R\&D. In accordance with this approach, we use the presence of $R \& D$ activities as an indicator of the existence of absorptive capacities at the plant level. In addition, in order to capture the learning capacity accumulated by firms in the processes of imitation and technology adoption - even if strictly defined R\&D activities are not performed - we also consider the experience associated with the introduction of new product lines as a component of their absorptive capacity.

The rest of the paper is structured as follows. Section 2 presents the theoretical model used as a framework and the empirical specification. Section 3 describes the data and Section 4 reports regression results. Section 5 discusses robustness checks and Section 6 offers concluding remarks.

\section{Theoretical Model and Empirical Specification}


This section presents the theoretical framework used to investigate the effect of different international economic activities on the demand for skilled labor. We assume that manufacturing plants choose their variable inputs - skilled and unskilled labor - by minimizing a restricted variable cost function subject to an output constraint. For plant $i$, the minimum labor cost of producing value added $V A_{i}$ given its capital stock $K_{i}$, which is a quasi-fixed input, its internal absorptive capacity, $T_{i}^{1}$, and its engagement in an international economic activity, $T_{i}^{2}$, is given by: ${ }^{14}$

$$
V C_{i}=f\left(w_{i}^{S}, w_{i}^{U}, K_{i}, V A_{i}, T_{i}^{1}, T_{i}^{2}\right)
$$

where $w_{i}{ }^{S}$ is the wage paid to skilled workers and $w_{i}^{U}$ is the wage paid to unskilled workers. ${ }^{15}$ We use a translog functional form for logarithmic variable costs as in Berman et al. (1994):

$$
\begin{aligned}
\ln V C_{i}= & \beta_{0}+\beta_{S} \ln w_{i}^{S}+\beta_{U} \ln w_{i}^{U}+\beta_{K} \ln K_{i}+\beta_{V} \ln V A_{i}+\beta_{T 1} T_{i}^{1}+ \\
& \beta_{T 2} T_{i}^{2}+1 / 2 \phi_{S S}\left(\ln w_{i}^{S}\right)^{2}+1 / 2 \phi_{U U}\left(\ln w_{i}^{U}\right)^{2}+1 / 2 \phi_{K K}\left(\ln K_{i}\right)^{2}+ \\
& 1 / 2 \phi_{V V}\left(\ln V A_{i}\right)^{2}+1 / 2 \phi_{T 1 T 1}\left(T_{i}^{1}\right)^{2}+1 / 2 \phi_{T 2 T 2}\left(T_{i}^{2}\right)^{2}+ \\
& 1 / 2 \phi_{S U}\left(\ln w_{i}^{S} * \ln w_{i}^{U}\right)+1 / 2 \phi_{U S}\left(\ln w_{i}^{S} * \ln w_{i}^{U}\right)+\phi_{S K}\left(\ln w_{i}^{S} * \ln K_{i}\right)+ \\
& \phi_{U K}\left(\ln w_{i}^{U} * \ln K_{i}\right)+\phi_{S V}\left(\ln w_{i}{ }^{S} * \ln V A_{i}\right)+\phi_{U V}\left(\ln w_{i}^{U} * \ln V A_{i}\right)+ \\
& \phi_{S T 1}\left(\ln w_{i}^{S} * T_{i}^{1}\right)+\phi_{S T 2}\left(\ln w_{i}{ }^{S} * T_{i}^{2}\right)+\phi_{U T 1}\left(\ln w_{i}^{U} * T_{i}^{1}\right)+ \\
& \phi_{U T 2}\left(\ln w_{i}^{U} * T_{i}^{2}\right)+\phi_{K V}\left(\ln K_{i} * \ln V A_{i}\right)+\phi_{K T 1}\left(\ln K_{i} * T_{i}^{1}\right)+ \\
& \phi_{K T 2}\left(\ln K_{i} * T_{i}^{2}\right)+\phi_{V T 1}\left(\ln V A_{i} * T_{i}^{1}\right)+\phi_{V T 2}\left(\ln V A_{i} * T_{i}^{2}\right) .
\end{aligned}
$$

Differentiating the cost function with respect to $\ln w_{i}^{S}$, using Shephard's lemma and making the assumptions of (i) symmetry of the effect of relative input prices on input demands and (ii) ${ }^{14}$ For simplicity, we ignore the plant's choice of intermediate inputs. Hence, output is measured by value added and the plant's variable costs are simply labor costs.

${ }^{15}$ For brevity in the exposition, we describe $T_{i}^{1}$ as a single variable. However in our empirical implementation, $T_{i}^{1}$ is a vector of two indicator variables: one for plants doing $R \& D$ and another for plants introducing new product lines. Also, in most specifications $T_{i}^{2}$ is a single variable but in Section 4.4, we allow $T_{i}^{2}$ to be a vector including multiple international activities. 
homogeneity of degree one in input prices, one obtains the following equation representing the relative demand for skilled labor: ${ }^{16}$

$$
\frac{d \ln V C_{i}}{d \ln w_{i}{ }^{S}}=\frac{w_{i}^{S} L_{i}^{S}}{V C_{i}}=\alpha+\phi_{S U} \ln \left(\frac{w_{i}{ }^{S}}{w_{i}{ }^{U}}\right)+\phi_{S K} \ln K_{i}+\phi_{S V} \ln V A_{i}+\phi_{S T 1} T_{i}^{1}+\phi_{S T 2} T_{i}^{2} .
$$

The dependent variable in Eq. (3) is the wage bill share of skilled workers. A positive $\phi_{S T 1}$ suggests that the plant's absorptive capacity is skill biased and a positive $\phi_{S T 2}$ suggests that the international economic activity that the plant is engaged in is skill biased. Finally, a positive $\phi_{S K}$ indicates that capital and skilled labor are complementary. Constant returns to scale would be verified if $\phi_{S K}=-\phi_{S V}$. However, we do not impose constant returns to scale in our specifications. Instead, we modify the way in which capital and value added enter the equation and estimate directly a parameter representing returns to scale. ${ }^{17}$ To obtain an estimable equation, we add a stochastic error $\varepsilon_{i}$ to Eq. (3) representing e.g., measurement or optimization error. The estimable equation is given by:

$$
\frac{w_{i}^{S} L_{i}^{S}}{V C_{i}}=\alpha+\beta_{1} \ln \left(\frac{w_{i}^{S}}{w_{i}^{U}}\right)+\beta_{2} \ln \left(\frac{K_{i}}{V A_{i}}\right)+\beta_{3} \ln V A_{i}+\phi_{S T 1} T_{i}^{1}+\phi_{S T 2} T_{i}^{2}+\varepsilon_{i}
$$

The estimation of Eq. (4) is subject to an econometric problem: the difficulty in identifying the effect of relative wages on the demand for skilled labor. The cross-sectional variation in relative wages is generally not exogenous (i.e., due to variation in actual prices of labor) but instead is often due to variation in the unobserved quality of labor. This problem could be addressed by instrumental variables estimation, if instruments for the relative wage term were available. Following Berman et al. (1994), most researchers have estimated variants of Eq. 16Shephard's lemma states that the derivative of the restricted cost function with respect to input X's price equals input $\mathrm{X}$ 's demand. If $\mathrm{X}$ is skilled labor, the lemma states that $\frac{d V C}{d w^{S}}=L^{S}$. Multiplying and dividing this equality by $\frac{w^{S}}{V C}$, an elasticity expression is obtained: $\frac{d V C}{d w^{S}} * \frac{w^{S}}{V C}=\frac{w^{S} L^{S}}{V C}$. For our case of logarithmic variable costs, the following equality holds: $\frac{d \ln V C}{d \ln w^{S}}=\frac{d V C}{d w^{S}} * \frac{w^{S}}{V C}=\frac{w^{S} L^{S}}{V C}$. The assumption of symmetry of the effect of relative input prices on input demands implies $\phi_{S U}=\phi_{U S}$. The assumption of homogeneity of degree one in input prices implies $\phi_{S U}=-\phi_{S S}$.

17The expression $\phi_{S K} \ln K_{i}+\phi_{S V} \ln V A_{i}$ in Eq. (3) is rewritten as $\beta_{2} \ln \left(\frac{K_{i}}{V A_{i}}\right)+\beta_{3} \ln V A_{i}$ in Eq. (4) with $\beta_{2}=\phi_{S K}$ and $\beta_{3}=\phi_{S K}+\phi_{S V}$. Returns to scale are given by $\beta_{3}$. 
(4) dropping the relative wage term. ${ }^{18}$ We also focus on estimation results that exclude the relative wage term, but we include industry and region dummy variables which may correct for differences in the excluded term and correct for other systematic differences in the demand for skilled workers across industries and regions.

Better plant managers are more likely to engage in international economic activities (e.g., by being more able to attract foreign investment), have more absorptive capacity to use advanced technologies but they also may choose more skilled workers. Omitting manager quality from the estimation could lead to a correlation between the error term in Eq. (4) and variables $T_{i}^{1}$ and $T_{i}^{2}$ and hence an upward bias in the main coefficients of interest. To address this potential bias, we include a proxy for managerial quality, $M Q_{i}$, in the regressions. Our final estimable equation for plant $i$ in industry $j$ and region $r$ is therefore given by:

$$
\frac{w_{i j r}^{S} L_{i j r}^{S}}{V C_{i j r}}=\alpha+\beta_{2} \ln \left(\frac{K_{i j r}}{V A_{i j r}}\right)+\beta_{3} \ln V A_{i j r}+\beta_{4} T_{i j r}^{1}+\beta_{5} T_{i j r}^{2}+\beta_{6} M Q_{i j r}+I^{i}+I^{r}+\varepsilon_{i j r} .
$$

We also consider specifications where the dependent variable is the share of skilled workers in total employment instead of their share in the wage bill, although these are not directly derived from the theoretical framework.

\section{Data and Cross Tabulation Results}

\subsection{Data}

In Table 1, we present some major economic facts for the countries analyzed in this paper, Brazil and China. While the per capita income level in Brazil is almost three times that in China, the average level of education of the population is higher in China. Over the 1990s, China achieved a greater degree of openness than Brazil, reflected in GDP shares of exports, imports and FDI that were twice as large on average in China. However, both countries experienced 
an increase in international integration with e.g., exports growing much faster than income, making it interesting to analyze the link between international activities and the demand for skilled labor.

Our analysis draws on survey data recently collected by the World Bank from manufacturing establishments in Brazil and China under the Investment Climate Assessment initiative. ${ }^{19}$ The surveys applied a (mostly) common questionnaire covering a variety of topics (e.g., infrastructure, finance, etc.) to random samples of establishments and were implemented in China in 2001 in partnership with a local statistical institute and in Brazil in 2003 in partnership with a local consulting firm. ${ }^{20}$ The random samples were drawn from a sampling frame of manufacturing establishments in each country. The sample design varied by country: (i) in Brazil, stratified samples based on industry-state-size were drawn for thirteen states and all the regressions estimated in the paper are weighted accordingly and (ii) in China, the sample was randomly chosen for each of five cities. ${ }^{21}$

Both surveys cover different industries and regions and the entire range of plant sizes, but the exact composition of the samples differs across countries. In Table 2, we show the distribution of plants across industries (Panel A) and across size groups (Panel B) for each country. ${ }^{22}$ The apparel, auto-parts and electronics industries are covered in both countries. Large plants represent about a half of the sample for Brazil whereas for China the majority of plants in the sample are small.

19More information on the initiative can be found at http://www.worldbank.org/privatesector/ic/.

20The survey questionnaires also included some country specific questions. For our purposes, the relevant survey questions relate to the workforce, technology and innovation, production and costs, ownership structure, trade and manager characteristics.

${ }^{21}$ In Brazil, the sampling frame consisted of the listings of manufacturing establishments provided by IBGE (the national statistical office). The states covered in Brazil are: Amazonas, Bahia, Ceará, Goiás, Maranhão, Mato Grosso, Minas Gerais, Paraíba, Paraná, Rio de Janeiro, Rio Grande do Sul, Santa Catarina and São Paulo. In China, the sampling frame consisted of an electronic list of firms in each of the cities covered: Beijing, Chengdu, Guangzhou, Shanghai and Tianjin.

${ }^{22}$ Size groups are defined according to a plant's total number of permanent employees. 


\subsubsection{Skills Measures}

Measures of skills are needed to construct the dependent variables in the regressions: wage bill shares and employment shares of skilled workers. Our surveys provide information on employment, wages and the average number of years of education for five types of workers (management, professionals, skilled production workers, unskilled production workers and other nonproduction workers). ${ }^{23}$ We consider total compensation i.e., wages and salaries plus bonuses and other benefits as the measure of wages. Our first measure of skilled workers is based on occupation: nonproduction workers defined as the sum of management, professionals and nonproduction workers. ${ }^{24}$ Most previous studies use datasets for which the skilled/unskilled workers distinction can be proxied only by this nonproduction/production worker distinction. However, this is imperfect since, for example, some of the nonproduction workers are in fact engaged in low skilled tasks. Our second measure of skilled workers is also based on occupation but improves upon the nonproduction/production worker distinction: workers in managerial, engineering and technical occupations, defined as the sum of management and professionals. ${ }^{25}$ This measure excludes the type of workers called in our surveys other nonproduction workers i.e., those that are not directly involved in production but that are neither part of management nor classified as professionals. ${ }^{26}$ Our third measure of skilled workers is based on education: workers with at least some college education. ${ }^{27}$ For China, we use information on average educational levels for each type of workers. Skilled worker wage bill shares (employment shares) are defined

${ }^{23} \mathrm{~A}$ detailed definition of these five types of workers is available from the authors upon request. In the Chinese survey, some of the worker types have different labels (professionals are called engineering and technical personnel, skilled production workers are called basic production workers and unskilled production workers are called auxiliary production workers) and some worker types are actually different but can be mapped into these five worker types (service personnel and other employees are mapped into other nonproduction workers).

${ }^{24}$ In this case, unskilled workers are production workers defined as the sum of skilled production workers and unskilled production workers.

25 In this case, unskilled workers are defined to be the sum of skilled production workers, unskilled production workers and other nonproduction workers.

${ }^{26}$ An example of such workers would be janitors.

27In this case, unskilled workers are defined as workers that have completed secondary education or less. 
as the sum of wages (number of workers) of all types of workers which have an average number of years of education strictly larger than the number of years needed to complete secondary school divided by the total wage bill (total number of employees). ${ }^{28}$ For Brazil, we use direct information on the percentage of workers with some college education. ${ }^{29}$

In Table 3 Panel A, we present summary statistics on wage bill shares and employment shares of skilled workers according to our three measures. In both countries, wage bill shares and employment shares of nonproduction workers are larger than those of workers in engineering, technical and managerial occupations (by definition) and these are in turn larger than those of workers with college education. For any given definition of skills, average wage bill shares are larger than average employment shares. According to all skills measures, Brazil has lower average shares of skilled workers than China.

\subsubsection{Absorptive Capacity and International Economic Activities}

As measures of plants' learning and absorptive capacities, we use a dummy variable for R\&D expenditures and a dummy variable for the introduction of new product lines. ${ }^{30}$ To measure the presence of international economic activities, we use a dummy variable for plants that export, the plant's share of sales that are exported, a dummy variable for plants that are foreign-owned, the plant's foreign ownership share, a dummy variable for plants that use imported inputs and the plant's imported inputs share. For Brazil, we use data on direct exports, i.e. those not done through a distributor, whereas for China we use data on total exports since the survey does not distinguish between direct and indirect exports. ${ }^{31}$ In Table 3 Panel B, summary statistics are shown for the different measures of absorptive capacity and international economic activities.

28The implicit assumption made in constructing this measure is that all workers of a given type have exactly the average level of education of that worker type.

29 Wage bill shares for this education-based measure of skills are not available for Brazil.

$30 \mathrm{R} \& \mathrm{D}$ and the introduction of new product lines can be viewed as, respectively, an input into and an output from a knowledge production function (see Chennells and Van Reenen, 1999).

31However, the empirical findings for Brazil are very similar when considering total exports. 


\subsubsection{Other Variables}

Estimating Eq. (5) also requires the use of plant-level data on sales and materials costs to construct value added, the book value of machinery and equipment to measure the capital stock, industry and region dummy variables. To reduce the influence of extreme values, we eliminate from the estimation the top and bottom $1 \%$ of observations for the ratio of capital to value added in each industry. ${ }^{32}$ The industry dummy variables are based on the industries shown in Table 2. ${ }^{33}$ The region dummy variables represent thirteen states in Brazil and five cities in China. Finally, we rely on information on the plant's main manager level of education as a proxy for manager quality using three dummy variables: managers with secondary education, managers with college education and managers with graduate education.

\subsection{Cross-Tabulation Results}

The results from cross-tabulations between the wage bill shares of different measures of skilled labor and either measures of absorptive capacity or international economic activities are presented in Table 4 for Brazil (Panel A) and China (Panel B). ${ }^{34}$ For each country, we calculate the difference between the average wage bill share of skilled workers for (i) plants with "better" absorptive capacity or (ii) plants "more" engaged in international economic activities and the average wage bill share of skilled workers for other plants and we test whether those differences in averages are statistically significant. ${ }^{35}$ In Brazil, there is a positive and significant correlation between the wage bill share of skilled workers and both measures of absorptive capacity and international activities, however skills are measured. In China, the measures of absorptive capacity and FDI are also positively and significantly associated with wage bill

$32 \mathrm{As}$ industries differ significantly in their capital intensity, the elimination is done for each industry separately. 33 All the empirical results obtained for Brazil and China described in Section 4 are maintained considering industry dummy variables at a more disaggregated level: 4-digit ISIC revision 3.

34 For Brazil, Table 4 shows employment shares of workers with college education instead of the corresponding wage bill shares which are unavailable.

35 For dummy variables, a plant with "better" absorptive capacity or "more" engaged in international economic activities has the corresponding dummy variable equal to one. 
shares of skilled workers. For two out of three skills definitions, exports are negatively and significantly associated with wage bill shares of skilled workers while imported inputs exhibit a non-significant correlation with the demand for skilled labor for two out of three measures of skilled labor. These cross-tabulations point out to important differences in wage bill shares depending on the international economic activities that plants are engaged in and depending on the country under analysis which are interesting to pursue in a regression framework.

\section{Regression Results}

In this section, we discuss the results from estimating Eq. (5) separately for each country by ordinary least squares (OLS) with standard errors corrected for possible heteroskedasticity (White correction) and weighted by survey weights for Brazil. ${ }^{36}$ We present the results in Tables 5 through 12 organized by international economic activity. In each table, the columns represent the dependent variables in the regressions (wage bill shares and employment shares of skilled workers) and the rows show the coefficients and standard errors of absorptive capacity measures and international economic activities, the R-squared and the number of observations in each regression.

\subsection{Imported Inputs}

Table 5 presents regression results for the estimation of Eq. (5) including as the international economic activity a dummy variable for plants that use imported intermediate inputs. In the case of Brazil, that dummy has a positive and significant effect on wage bill shares and employment shares of skilled workers, regardless of the skilled labor definition. Quantitatively, the magnitude of the effects is largest for the employment share of workers with college education, which increases by about $36 \%$ for plants that use imported inputs, and is lowest for the employment 36We also estimate Eq. (5) for Brazil using unweighted OLS to test whether or not sample weights should be used following Deaton (1997), p. 72. We conclude that sample weights have to be used in the estimation. 
share of nonproduction workers, which increases by about $12 \%$ for those plants (the average effect, across the five different measures of skills is 19\%). ${ }^{37}$ When expressed as elasticities, the effects are somewhat smaller on employment shares when compared to wage bill shares, suggesting that the relative wages of skilled workers may be slightly larger in plants which use imported inputs, thus reinforcing the effect of the latter on employment.

Very different results are obtained for China, where the use of imported inputs has a significant negative effect on the employment shares of nonproduction workers and of workers in engineering, technical and managerial occupations. This suggests that Chinese plants that use imported inputs concentrate to a larger extent than their competitors in production activities that are intensive in unskilled labor. The magnitude of these effects is similar to those found for Brazil, although with the reverse sign: relative to other plants, those that use imported inputs have employment shares that are $15 \%$ lower for nonproduction workers and $8 \%$ lower for workers in engineering, technical and managerial occupations. The finding that the effects on the corresponding wage bill shares are negative but not significant indicates that while plants that use imported inputs employ relatively fewer skilled workers, the wages they pay to those workers are higher than those paid in other plants, as was also found in Brazil.

As an alternative to the use of a dummy variable, and to test the robustness of the results with that approach, we consider in Table 6 the share of intermediate inputs that are imported as the international activity. The results are qualitatively similar to those reported in Table 5. A higher share of imported inputs is associated with a greater demand for skilled workers in Brazil and with a lower demand for those workers in China and most of the effects are significant.

Although our focus is on the effect of different international economic activities on skilled $\overline{37 \text { These and other elasticities reported below }}$ are calculated as the ratio of the coefficient on the relevant dummy variable to the average of the corresponding skilled labor share in the group of plants for which the dummy variable is zero: e.g., the ratio of the coefficient on the imported inputs dummy to the average wage bill share of workers with college education of plants that do not import inputs. 
labor demand, it is worth commenting briefly on the estimated coefficients on the other variables included in Eq. (5). The variables measuring plants' absorptive capacity, for instance, are expected to be positively related with the various measures of skill demand. This is indeed the case in Brazil and China when the dummy variable for R\&D activities is employed, as this variable has a positive and significant effect on all measures of skill demand. The second measure of absorptive capacity, the dummy variable for plants that introduced in the market a major new product line during the years preceding the survey, is also found to be positively linked to skill demand in all specifications for Brazil and China. However, in Brazil it is significant only when employment shares are used as left-hand-side variables, suggesting a compensating effect on the relative wages of skilled workers. In China, the introduction of new product lines has significant effects only for the skills measures based on workers in engineering, technical and managerial occupations.

Although the corresponding coefficients are not reported in the tables, all regressions include the capital to value added ratio, value added, and dummy variables measuring the level of education of the plant's general manager. ${ }^{38}$ The results for the first two variables can be summarized as follows. The coefficients on the capital to value added ratio are negative in Brazil and China indicating substitutability between capital and skilled labor. In Brazil, those coefficients are significant only when skills are measured based on workers in engineering, technical and managerial occupations. In China, significant negative coefficients are found for all skills measures. The results for value added are not clear-cut, as the sign of the corresponding coefficients alternates depending on the measure of skills used. In Brazil, those coefficients are negative and significant, indicating decreasing returns to scale, when the dependent variable is the employment share of workers in engineering, technical and managerial occupations. However, the opposite result is

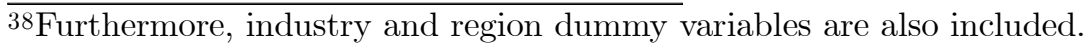


found when the dependent variable is the wage bill share of nonproduction workers. In China, the coefficients are negative and significant for three out of six dependent variables.

The results for the variables representing the level of education of the plants' general manager confirm that they are relevant determinants of the demand for skilled workers, although in general positive significant effects are found only when the manager's level of education includes at least some college education and, more frequently, when managers have also completed graduate studies. Moreover, in Brazil significant effects are found only when the employment shares of college-educated workers or of workers in engineering, technical and managerial occupations are used as left-hand-side variables. The findings on the role of the manager's educational level, on absorptive capacity, on value added and on the ratio of capital to value added remain generally unchanged when different international economic activities are considered. ${ }^{39}$

\subsection{Exports}

In Tables 7 and 8, we report estimates of Eq. (5) when an export dummy or export shares are the international economic activities considered. In Brazil, we find different results depending on whether the export dummy or export shares are used. The results in Table 7 with the export dummy suggest, to some extent, that exporters demand more skilled workers. Indeed, the wage bill shares of nonproduction workers and of workers in engineering, technical and managerial occupations are significantly higher among exporting plants. In elasticity terms, the positive and significant effect of the export dummy is larger for the latter (19\%) than for the former group of workers (11\%). These findings could be viewed as evidence of a role of exports in transmitting skill-biased technology. Note, however, that these results are restricted to wage bill shares, suggesting that their effect could be working through higher relative wages among exporters. Also, the results in Table 8 with export shares indicate that plants with higher export $\overline{39 H e n c e, ~ f o r ~ b r e v i t y, ~ w e ~ w i l l ~ n o t ~ d i s c u s s ~ t h o s e ~ e f f e c t s ~ i n ~ t h e ~ s e c t i o n s ~ t h a t ~ f o l l o w . ~}$ 
shares have lower wage bill shares and lower employment shares of skilled workers. The effects are significant when the dependent variables are employment shares of either nonproduction workers or workers in engineering, technical and managerial occupations. This would suggest that, in fact, exporters are specializing in relatively unskilled labor-intensive products according to their comparative advantage. To gain a better understanding of these disparate results, we also estimate Eq. (5) including a different set of export dummy variables: one for plants exporting less than $10 \%$ of their output, another for plants exporting between $10 \%$ and $50 \%$ of their output and a third for plants exporting more than $50 \%$ of their output. The results indicate that plants with export shares up to $50 \%$ demand relatively more skilled workers, while plants exporting a majority of their output demand relatively less skilled workers. ${ }^{40}$ So, the results with the export dummy in Table 7 are driven by "minority" exporters whereas the results with export shares in Table 8 are driven by "majority" exporters.

In China, the results are unambiguous compared to Brazil. We find evidence of a negative and significant effect of the export dummy and of export shares on wage bill shares and employment shares of skilled workers for all skills definitions. ${ }^{41}$ Plants that participate in export markets demand relatively less skilled workers. More specifically, those plants have wage bill shares of nonproduction workers that are $50 \%$ lower than in nonexporter plants, and have employment shares of nonproduction workers and wage bill shares and employment shares of workers in engineering, technical and managerial activities that are more than $30 \%$ lower than those in nonexporter plants. This evidence suggests that Chinese plants are specializing according to their comparative advantage, in unskilled-labor-intensive activities and this effect more than compensates for any impact that exporting may have in terms of technology diffusion. In elasticity terms, the effects of the export dummy are larger (more negative) for employment 40These regression results are available from the authors upon request. 41 One exception occurs in terms of significance for the export dummy when the dependent variable is the wage bill share of workers with some college. 
shares than for wage bill shares which could indicate that while employment of skilled workers is lower in exporter plants their wages may be larger in those plants.

\subsection{Foreign Ownership}

The results for the specifications that employ a foreign ownership dummy as the plant's international economic activity are reported in Table 9. For Brazil and China, the evidence shows that plants with FDI exhibit a significantly larger demand for skilled workers, regardless of how the latter are defined, the only exception being the regressions with employment shares of nonproduction workers. The magnitude of these effects is large, particularly in Brazil when the focus is placed on the demand for workers in engineering, technical and managerial occupations or on the demand for workers with college education. As an example, for Brazilian plants the presence of at least some FDI is associated with wage bill shares and employment shares of workers in engineering, technical and managerial occupations that are respectively $60 \%$ and $46 \%$ larger than those in their domestic competitors. Similarly, Chinese plants with FDI have wage bill shares and employment shares of workers with college education that are respectively $38 \%$ and $29 \%$ larger than those in domestically-owned plants.

In order to test the robustness of these findings, we report in Table 10 the estimates from regressions where plants' FDI shares measure their involvement in international economic activities. The results are qualitatively very similar to those obtained with the FDI dummy. In Brazil, higher FDI shares are associated, in most cases, with a greater demand for skilled labor, and the same is true for China, although the effects are significant for only two of the dependent variables.

\subsection{Multiple International Economic Activities}

Our analysis in Sections 4.1-4.3 considers the effect of each international economic activity 
separately on the demand for skilled labor of manufacturing plants in Brazil and China. Kraay et al. (2001) argue that these various international economic activities are not independent, rather they are highly interrelated, so focusing on one activity and ignoring the others may over or underestimate its true effects. ${ }^{42}$ For this reason, we also estimate our main specification considering simultaneously various international economic activities. Table 11 shows the results from regressions that include an imported inputs dummy, an FDI dummy and an export dummy. In Brazil, the estimates indicate that the use of imported inputs, exports and FDI contribute to a higher demand for skilled labor. The sign and significance of the coefficients are very similar to those described in Sections 4.1-4.3. This could indicate, as suggested by Kraay et al. (2001), that the coefficients from the regressions with a single international economic activity pick up also the effects of the other omitted activities. In China, there is a negative effect of the use of imported inputs and exports on the demand for skilled labor but a positive effect of FDI on that demand. Again, these findings parallel those from the regressions including a single international activity, and the magnitude of the FDI dummy coefficients is larger in the regressions including all activities.

Table 12 presents the regression results including imported inputs shares, FDI shares and export shares to measure international activities. In Brazil, we find that higher imported inputs shares and FDI shares are linked to a higher demand for skilled labor but higher exports shares are linked to a lower demand for skilled labor. These findings are very close to those in Sections 4.1-4.3 but the estimated coefficients are smaller when all activities are considered simultaneously. In China, the results suggest that imported inputs shares and exports shares have a negative effect on wage bill shares and employment shares of skilled workers whereas the opposite is verified for FDI shares. Again, these findings are similar to those from the regressions $\overline{42}$ Also, Harrison and Hanson (1999) and Pavcnik (2003) include simultaneously different technology and international integration variables in their regressions. 
with a single international activity. The coefficients on imported inputs and FDI are larger and those on exports are smaller than those in, respectively, Tables 6,10 and 8.

\section{Robustness}

To test the robustness of the results presented in Section 4, we consider different empirical specifications and estimation techniques.

\subsection{Relative Wages and Relative Employment}

The aforementioned results using wage bill shares and employment shares of skilled workers as dependent variables suggest that the use of imported inputs, exports and FDI are associated with higher relative wages for skilled workers. Indeed, the elasticities of wage bill shares of skilled workers with respect to those three international activities are generally larger than the corresponding elasticities for employment shares. In order to better identify the separate effects of international activities on relative wages and on relative employment of skilled workers, we now discuss the results from specifications that use those variables as dependent variables in Eq. (5). ${ }^{43}$ We report in Tables 13-15 only the results with imported inputs shares, export shares and FDI shares as the results with the corresponding dummy variables are qualitatively very similar.

For Brazil, the estimates confirm that larger shares of imported inputs and larger export shares are associated with higher relative wages of skilled workers. Foreign ownership, however, does not have significant effects on the relative wages of skilled Brazilian workers. For both imported inputs and FDI, the effects on relative skilled employment are found to be positive and significant, but the effects of exports are negative. ${ }^{44}$ For China, we find that the three afore43This approach is followed also by Harrison and Hanson (1999).

${ }^{44}$ When the effects of exports are allowed to vary by ranges of export shares, we find that their negative impact on the relative employment of skilled workers is restricted to the plants for which exports represent at least $50 \%$ of total sales. However, higher relative wages of skilled workers among exporters are found for all ranges of export shares. 
mentioned international activities are associated with higher relative wages for skilled workers. However, the effects on relative skilled employment are negative and significant for imported inputs and export shares and are not significant for FDI shares.

\subsection{Industries with Comparative Advantage}

The effect of international economic activities on the demand for skilled labor may depend on whether or not the plant belongs to an industry with comparative advantage. We follow Yeats (1998) in calculating revealed comparative advantage indexes for each 4-digit ISIC revision 3 industry in Brazil (for 2001) and in China (for 1999) and based on these indexes, we construct dummy variables identifying the industries with comparative advantage in each country. ${ }^{45}$ We estimate a modified version of Eq. (5), where the international activity $T_{i j r}^{2}$ enters separately and interacted with the dummy variable for comparative advantage industries and show the results in Tables 16-18. ${ }^{46}$ In Table 16, the coefficients on imported inputs shares for Brazil are positive and close to those in Table 6 . The coefficients on the interaction with the comparative advantage dummy are negative in three cases but never significant. The total effect of imported inputs on the demand for skilled labor is positive suggesting that our earlier finding that imported inputs allow Brazilian plants access to skill-biased technology flows is not counteracted by the fact that plants importing inputs in comparative advantage industries may be engaging in production activities intensive in unskilled labor. For China, the effect of imported inputs shares per se on the demand for skilled labor is negative, except for education-based skills measures. Chinese plants that import higher shares of inputs in industries with comparative advantage have an even lower demand for skilled workers. This provides support to our interpretation of the negative

45We use detailed trade flows for Brazil, China and the world taken from World Integrated Trade Solution (WITS) to compute the revealed comparative advantage indexes as detailed in Yeats (1998). Industries with values for those indexes larger than one have revealed comparative advantage.

${ }_{46}$ The results with imported inputs shares, export shares and FDI shares are qualitatively similar to those with the corresponding dummy variables, hence we discuss here only the results with shares. 
effect of imported inputs on skill demand of Chinese plants as being driven by their specialization according to comparative advantage.

In Table 17, we find that Brazilian plants with higher export shares have higher wage bill shares but significantly lower employment shares of skilled workers. In industries with comparative advantage, the effect of exports on the wage bill shares of skilled workers is generally counteracted, thus becoming negative in those industries. Thus, the total effect of exports is negative for all skills measures in industries with comparative advantage. In the remaining industries that effect is negative only in the specifications that use employment shares as dependent variables. The results are positive and not significant when wage bill shares are used, possibly due to the positive effect of exports on relative wages reported in the previous section. For China, the coefficients on export shares are negative and generally significant. In industries with comparative advantage, exporting plants have a much lower demand for skilled workers than other plants. This finding is consistent with that obtained for imported inputs shares and suggests that plants in industries with comparative advantage specialize to a greater extent in the production of goods intensive in the use of unskilled labor.

Table 18 shows that Brazilian plants with larger FDI shares demand relatively more skilled workers and the effects are very similar to those in Table 10. The coefficients on the interaction term are generally positive, although not significant. Hence, in Brazil, foreign ownership plays a role in transferring skill-biased technology in all industries, including those with comparative advantage. In China, the coefficients on FDI shares are positive and significant and larger in magnitude that those in Table 10. The coefficients on the interaction term are negative but the overall effect of FDI on the demand for skilled labor of plants in industries with revealed comparative advantage is still positive, indicating that the role of FDI in diffusing technology is only partly counteracted by a specialization of Chinese plants in the production of goods 
intensive in unskilled labor.

\subsection{State-Owned and Privately-Owned Plants in China}

State-owned enterprises in China are believed to be less efficient and operate differently from privately-owned enterprises in terms of e.g., management, budgets, competition. The regressions described in Section 4 for China include both privately-owned and publicly-owned plants. However, it is possible that the relationship between international activities and the demand for skilled labor is affected by the type of ownership. We address this possibility as follows. First, we add to Eq. (5) a dummy variable for collective plants and a dummy variable for state-owned plants. ${ }^{47}$ The effects of imported inputs and exports on the demand for skilled labor are very similar in magnitude and significance to those discussed in Section $4 .{ }^{48}$ For FDI, however, the coefficients lose significance in some cases. The dummy variables for collective plants and for state-owned plants have generally negative coefficients, significant for state-owned plants. An important exception is verified when skill demand is measured by employment shares of nonproduction workers: the coefficients on the dummy variables for collective plants and for state-owned plants are positive and significant. Nonproduction workers include, among others, administrative and services personnel, so we interpret this finding as reflecting some inefficiency of publicly-owned plants which forces them to have a larger share of administrative workers. ${ }^{49}$

Second, we estimate Eq. (5) separately for privately-owned plants and for publicly-owned (collective or state) plants. The effects of imported inputs, exports and FDI on the demand for skilled labor for privately-owned plants are relatively similar to those in Tables 5-12, whereas the effects for publicly-owned plants are also generally similar but often not significant. ${ }^{50}$

47The Chinese sample is constituted by 646 privately-owned plants, 158 collective plants and 194 state-owned plants.

48These results are available upon request.

${ }^{49}$ Note, however, that these workers' wage bill shares in collective or state-owned plants are lower than in privately-owned plants.

50This lack of significance is likely due to the smaller sample size. However, interestingly, we find that the positive effect of R\&D on skill demand is often stronger for publicly-owned plants than for privately-owned plants. 


\subsection{Instrumental Variables}

Our three international economic activities - imported inputs shares, export shares and FDI shares - can arguably be considered endogenous in Eq. (5), due to the presence of reverse causality. Thus, for example, foreign companies may choose to invest in plants that already exhibit relatively higher shares of skilled workers, and both exports and imports of inputs may be more likely to be pursued by plants whose workers possess higher educational levels, that can be necessary to engage in contacts and negotiations with foreign customers or suppliers. To address this problem, Tables 19-21 present results from estimating Eq. (5) using instrumental variables (IV). ${ }^{51}$ In the case of imported inputs, the positive and negative effects that were, respectively, reported for Brazil and China in Section 4.1 are preserved, and the magnitude of the coefficients increases considerably (in absolute value). The specification tests support the endogeneity assumption for the share of imported inputs and the validity of the corresponding instruments.

In the case of exports, the IV estimates validate the negative effect previously found for China in Section 4.2, but the IV estimates are not significant for Brazil. In both countries, the instruments for export shares seem to be appropriately correlated with that variable in the first stage regressions and tests for overidentifying restrictions also support their validity. However, the first specification test reported in Table 20 suggests that in Brazil exports are not endogenous in Eq. (5), so that our previous OLS estimates are preferred on efficiency grounds.

The effects of FDI from IV estimation are still positive in Brazil, but they become negative and significant in four out of six cases in China. In those four cases, the specification tests support both the need for instrumental variables and the validity of the instruments adopted,

51Detailed lists of the instruments used are shown in the notes to Tables 19-21. They are based on industryregion averages of some of the endogenous variables and, in China, on the fraction of plants that have been restructured into shareholding companies and the average share of government-owned capital. In Brazil, we also use industry-level tariffs, import penetration rates and export shares taken from Muendler (2003a) and Muendler (2003b). 
thus suggesting that the positive effect of FDI on the demand for skilled workers that was previously obtained was the result of some endogeneity bias. In Brazil, the endogeneity of FDI is not supported by the corresponding test, so the OLS estimates are preferred to the IV estimates.

\section{Conclusion}

One of the most important benefits that developing countries can potentially reap from their increasing levels of integration in the world economy, besides the static gains associated with increased international specialization, is the access to technologies developed in industrialized countries. Indeed, the intrinsic difficulties associated with transferring technology through market transactions make international trade and investment crucial channels for the international diffusion of technology. Since most of the international income gaps are related to technology and productivity gaps, increases in international economic integration are expected to go a long way towards reducing the enormous inequalities existing between rich and poor countries.

But what about the effects on the levels of inequality found within developing countries? The evidence from research conducted for the U.S. and other industrialized countries suggests that skilled-biased technological change has been the main factor driving increases in inequality between skilled and unskilled workers. Thus, one could expect the same effects in developing countries, already characterized by high levels of inequality, as they increasingly adopt technologies developed in the industrialized world. However, as firms in developing countries expand their international economic activities, one could also expect a greater exploitation of their countries' comparative advantage in the production of goods that make intensive use of unskilled labor. This should lead to a greater demand for that type of labor, and could thus counteract the effects that a greater adoption of skill-biased technologies could exert on local levels of wage inequality. 
This paper investigates the relative weight of those two countervailing forces associated with increased international integration, obtaining new evidence on the effects of international economic activities on plant-level demand for skilled workers. Our findings suggest that even though in China the plants with international activities tend to pay higher relative wages to skilled workers, the use of imported inputs, exports and FDI are all associated with a lower demand for skilled labor. Thus, for Chinese plants engaged in some or all of these international economic activities, specialization according to the country's comparative advantage in goods intensive in unskilled labor appears to more than compensate for the access to skill-biased foreign technologies that is potentially associated with those activities. In Brazil, our results also support a negative effect of exports on skilled labor demand, but this effect is restricted to plants that export a majority of their output, as a positive effect on skilled labor demand is found for the remaining exporting plants. Moreover, in contrast to the evidence for China, we find that in Brazil both the use of imported inputs and FDI are linked to a greater demand for skilled workers, probably because these activities act as channels for the diffusion of skilledbiased technologies. All in all, it appears that there is no general answer to our initial question concerning the effects of increased levels of international integration on the relative demand for skilled labor in developing countries: while the results for China suggest negative effects, those for Brazil tend to warrant an opposite conclusion. Understanding the factors and country characteristics that underlie these different sets of results is arguably a worthwhile endeavor, which could be pursued to the extent that comparable plant-level data becomes available for a larger sample of developing countries. 


\section{References}

Autor, D., Katz, L., Krueger, A., 1998. Computing Inequality: Have Computers Changed the Labor Market? Quarterly Journal of Economics 113, 1169-1213.

Berman, E., Bound, J., Griliches, Z., 1994. Changes in the Demand for Skilled Labor within U.S. Manufacturing: Evidence from the Annual Survey of Manufactures. Quarterly Journal of Economics 109, 367-397.

Bloningen, B., Slaughter, M, 2001. Foreign-Affiliate Activity and US Skill Upgrading. Review of Economics and Statistics 83, 362-376.

Chennells, L., Reenen, J., 1999. Has Technology Hurt Less Skilled Workers?: An Econometric Survey of the Effects of Technical Change on the Structure of Pay and Jobs. The Institute for Fiscal Studies Working Paper Series No. W99/27.

Clerides, S., Lach S., Tybout, J., 1998. Is "Learning-By-Exporting" Important? MicroDynamic Evidence from Colombia, Mexico, and Morocco. Quarterly Journal of Economics $113,903-947$.

Coe D., Helpman E., Hoffmaister H., 1997. North-South Spillovers. Economic Journal 107, 134-149.

Cohen, W., Levinthal, L., 1989. Innovation and Learning: The Two Faces of R\&D. Economic Journal 99, 569-596.

Deaton, A., 1997. The Analysis of Household Surveys: A Microeconometric Approach to Development Policy. The Johns Hopkins University Press.

Doms, M., Dunne, T., Troske, K., 1997. Workers, Wages, and Technology. Quarterly Journal of Economics 111, 253-290.

Dunne, T., Haltiwanger, J., Troske, K., 1997. Technology and Jobs: Secular Changes and Cyclical Dynamics. Carnegie-Rochester Conference Series on Public Policy 46, 107-178.

Feenstra, R., Hanson, G., 1996a. Globalization, Outsourcing, and Wage Inequality. American Economic Review 86, 240-245.

Feenstra, R., Hanson, G., 1996b. Foreign Investment, Outsourcing and Relative Wages, in: Feenstra, R., Grossman, G., Irwin, D. (Eds.) Political Economy of Trade Policy: Essays in Honor of Jagdish Bhagwati. MIT Press. Cambridge.

Feenstra, R., Hanson, G., 1997. Foreign Direct Investment and Relative Wages: Evidence from Mexico's Maquiladoras. Journal of International Economics 42, 371-393.

Gorg, H., Strobl, E., 2001. Relative Wages, Openness and Skill-Biased Technological Change in Ghana. CREDIT Research Paper No. 01/18, Center for Research in Economic Development and International Trade, University of Nottingham.

Grossman, G., Helpman E., 1991. Innovation and Growth in the World Economy. MIT Press Cambridge, MA.

Hallward-Driemeier, M., Iarossi G., Sokoloff, K., 2002. Exports and Manufacturing Productivity in East Asia: A Comparative Analysis with Firm-Level Data. NBER Working Paper 8894. 
Harrison, A., Hanson, G., 1999. Who Gains from Trade Reform? Some Remaining Puzzles. Journal of Development Economics 59, 125-154.

Haskel, J., Heden, Y., 1999. Computers and the Demand for Skilled Labour: Industry and Establishment-Level Panel Evidence for the UK. Economic Journal 109, 68-79.

Keller, W., 1996. Absorptive Capacity: On the Creation and Acquisition of Technology in Development. Journal of Development Economics 49, 199-227.

Keller, W., 2004. International Technology Diffusion. Journal of Economic Literature, Forthcoming.

Lumenga-Neso, O., Olarreaga, M., Schiff, M., 2001. On 'Indirect' Trade-Related R\&D Spillovers. World Bank Policy Research Working Paper 2580.

Machin, S., Van Reenen, J., 1998. Technology and Changes in Skill Structure: Evidence from Seven OECD Countries. Quarterly Journal of Economics 113, 1215-1244.

Markusen, J., 1995. The Boundaries of Multinational Enterprises and the Theory of International Trade. Journal of Economic Perspectives 9, 169-189.

Muendler, M., 2003a. Tariff Series for Brazil, 1986-1999. Mimeograph (econ.ucsd.edu/muendler/brazil).

Muendler, M., 2003b. Series of Market Penetration by Foreign Products, Brazil 1986-1998. Mimeograph (econ.ucsd.edu/muendler/brazil).

Pavcnik, N., 2003. What Explains Skill Upgrading in Less Developed Countries? Journal of Development Economics 71, 311-328.

Slaughter, M., 2000. Production Transfer within Multinational Enterprises and American Wages. Journal of International Economics 50, 449-472.

Slaughter, M., 2002. Does Inward Foreign Direct Investment Contribute to Skill Upgrading in Developing Countries? Unpublished Manuscript, Dartmouth College.

Xu, B., Wang, J., 2000. Capital Goods Trade and R\&D Spillovers in the OECD. Canadian Journal of Economics 32, 1258-1274.

Wood, A., 1994. North-South Trade, Employment and Inequality. IDS Development Studies Series, Clarendon Press, Oxford.

Yeats, A., 1998. Does Mercosur's Trade Performance Raise Concerns about the Effects of Regional Trade Arrangements? World Bank Economic Review 12, 1-28. 
Table 1. Economic Facts

\begin{tabular}{|c|c|c|c|c|c|c|c|c|}
\hline & Population & (US\$) & $\begin{array}{c}\text { GDP } \\
\text { Growth } \\
\text { (avg. 1992- }\end{array}$ & GDP (avg. & $\begin{array}{c}\text { Avg. } \\
\text { Growth in } \\
\text { Real } \\
\text { Exports } \\
(1993-\end{array}$ & GDP (avg. & FDI/GDP & $\begin{array}{c}\text { Avg. Years } \\
\text { Education } \\
\text { of } \\
\text { Population }\end{array}$ \\
\hline & (2002) & (2002) & 2002) & 1993-2002) & 2002) & 1993-2002) & 1991-2000) & $(2000)$ \\
\hline Brazil & 175 & 2830 & 2.7 & 9.5 & 7.5 & 10.3 & 2.4 & 4.9 \\
\hline China & 1281 & 950 & 9.0 & 23.3 & 16.0 & 20.9 & 4.6 & 6.4 \\
\hline
\end{tabular}

Source: World Development Indicators, World Bank.

Table 2. Composition of the Samples

Panel A - Distribution of Plants across Industries

\begin{tabular}{lrc}
\hline & Brazil & China \\
\hline Food processing & $8 \%$ & \\
Textiles & $6 \%$ & \\
Apparel & $27 \%$ & $22 \%$ \\
Shoes and leather products & $11 \%$ & \\
Chemicals & $5 \%$ & \\
Machinery and equipment & $11 \%$ & \\
Electronics & $5 \%$ & $39 \%$ \\
Auto-parts & $8 \%$ & $22 \%$ \\
Furniture & $19 \%$ & \\
Electrical appliances & & $17 \%$ \\
Rubber and plastics & & \\
N. observations & 1603 & 994 \\
\hline
\end{tabular}

Panel B - Distribution of Plants across Size Categories

\begin{tabular}{lrr}
\hline & Brazil & China \\
\hline Plants with less than 50 employees & $53 \%$ & $60 \%$ \\
Plants with 50 to 150 employees & $28 \%$ & $27 \%$ \\
Plants with more than 150 employees & $19 \%$ & $13 \%$ \\
\hline
\end{tabular}

Note: the definition of size is based on the total number of permanent employees at a plant. 
Table 3. Summary Statistics

Panel A. Demand for Skilled Workers

\begin{tabular}{lccccccc}
\hline & \multicolumn{2}{c}{ Brazil } & \multicolumn{3}{c}{ Brazil weighted } & \multicolumn{2}{c}{ China } \\
\hline & Avg. & St.dev. & Avg. & St.dev. & Avg. & St.dev. \\
\hline Wage bill shares of: & & & & & & \\
Nonproduction workers & 0.32 & 0.18 & 0.31 & 0.006 & 0.46 & 0.24 \\
$\begin{array}{l}\text { Workers in engineering, technical and managerial } \\
\text { occupations }\end{array}$ & 0.22 & 0.15 & 0.22 & 0.005 & 0.39 & 0.23 \\
Workers with some college & & & & & 0.11 & 0.23 \\
Employment shares of: & & & & & & \\
Nonproduction workers & 0.22 & 0.14 & 0.22 & 0.005 & 0.38 & 0.24 \\
Workers in engineering, technical and managerial & & & & & & \\
occupations & 0.11 & 0.09 & 0.12 & 0.003 & 0.28 & 0.21 \\
Workers with some college & 0.08 & 0.10 & 0.08 & 0.004 & 0.09 & 0.19 \\
\hline
\end{tabular}

Panel B. Absorptive Capacity, International Economic Activities and Technology Diffusion

\begin{tabular}{lccc}
\hline & Brazil & Brazil weighted & China \\
\hline \% of plants doing R\&D & $40.8 \%$ & $40.8 \%$ & $42.4 \%$ \\
$\%$ of plants introducing new product lines & $67.5 \%$ & $65.7 \%$ & $22.1 \%$ \\
\hline \% of plants importing inputs & $44.2 \%$ & $41.2 \%$ & $41.4 \%$ \\
Avg. imported input share & $25.0 \%$ & $24.4 \%$ & $29.3 \%$ \\
$\%$ of plants exporting & $27.0 \%$ & $19.8 \%$ & $44.0 \%$ \\
Avg. export share & $23.5 \%$ & $19.7 \%$ & $53.1 \%$ \\
$\%$ of plants with foreign ownership & $5.4 \%$ & $4.0 \%$ & $31.1 \%$ \\
Avg. foreign owership share & $84.1 \%$ & $81.7 \%$ & $58.4 \%$ \\
\hline
\end{tabular}

Note: For Brazil, the column labeled 'Brazil weighted' shows the summary statistics using survey weights.

The averages of imported input shares, export shares, and foreign ownership shares are taken for, respectively, plants that import inputs, export and have foreign ownership. 
Table 4. Differences in Average Wage Bill Shares of Skilled Workers According to Plants' Absorptive Capacity and International Economic Activities

Panel A. Brazil (using survey weights)

\begin{tabular}{lrrr}
\hline Technology Variable & $\begin{array}{c}\text { Wage bill } \\
\text { sh. non- } \\
\text { production } \\
\text { workers }\end{array}$ & $\begin{array}{l}\text { Wage bill } \\
\text { sh. engin., } \\
\text { techn. and } \\
\text { managers }\end{array}$ & Empl. sh. \\
\hline R\&D & $0.05 * * *$ & $0.02 * *$ & college \\
New Product Lines & $0.05 * * *$ & $0.03 * *$ & $0.04 * * *$ \\
Use of Imported Materials & $0.07 * * *$ & $0.06 * * *$ & $0.03 * * *$ \\
Exports & $0.08 * * *$ & $0.05 * * *$ & $0.04 * * *$ \\
Foreign Ownership & $0.22 * * *$ & $0.18 * * *$ & $0.11 * * *$ \\
\hline
\end{tabular}

Panel B. China

\begin{tabular}{lrrr}
\hline Technology Variable & $\begin{array}{c}\text { Wage bill } \\
\text { sh. non- } \\
\text { production } \\
\text { workers }\end{array}$ & $\begin{array}{l}\text { Wage bill } \\
\text { sh. engin., } \\
\text { techn. and } \\
\text { managers }\end{array}$ & Wage bill \\
& $0.13 * * *$ & $0.12 * * *$ & college \\
\hline R\&D & $0.09 * * *$ & $0.10 * * *$ & $0.12 * * *$ \\
New Product Lines & -0.01 & 0.01 & $0.09 * * *$ \\
Use of Imported Materials & $-0.06 * * *$ & $-0.05 * * *$ & 0.00 \\
Exports & $0.03 * *$ & $0.05 * * *$ & $0.05 * * *$ \\
Foreign Ownership &
\end{tabular}

Note: The asterisks show the results of tests of equivalence of mean wage bill shares for plants that have "better" versus "worse" absorptive capacity and for plants that are "more" versus "less" engaged in international economic activities. $*$ represents significance at $10 \%, * *$ significance at $5 \%$ and $* * *$ significance at $1 \%$. 
Table 5. Skilled Labor Demand and Imported Inputs Dummy

\begin{tabular}{|c|c|c|c|c|c|c|c|}
\hline & Coefficients & $\begin{array}{c}\text { Wage } \\
\text { nonprod. }\end{array}$ & $\begin{array}{c}\text { Empl. } \\
\text { nonprod. }\end{array}$ & $\begin{array}{l}\text { Wage eng., } \\
\text { tech. and } \\
\text { man. occ. }\end{array}$ & $\begin{array}{l}\text { Empl. eng., } \\
\text { tech. and } \\
\text { man. occ. }\end{array}$ & $\begin{array}{c}\text { Wage some } \\
\text { college }\end{array}$ & $\begin{array}{c}\text { Empl. } \\
\text { some } \\
\text { college }\end{array}$ \\
\hline \multirow[t]{8}{*}{ Brazil } & R\&D & 0.019 & $0.038 * * *$ & 0.003 & $0.019 * * *$ & & $0.018 * *$ \\
\hline & & $(0.013)$ & $(0.010)$ & $(0.012)$ & $(0.006)$ & & $(0.008)$ \\
\hline & New product line & 0.014 & $0.029 * * *$ & 0.004 & $0.014 * *$ & & $0.016 * * *$ \\
\hline & & $(0.014)$ & $(0.009)$ & $(0.012)$ & $(0.006)$ & & $(0.005)$ \\
\hline & Imported inputs dummy & $0.044 * * *$ & $0.024 * *$ & $0.039 * * *$ & $0.014 * *$ & & $0.023 * * *$ \\
\hline & & $(0.014)$ & $(0.010)$ & $(0.012)$ & $(0.006)$ & & $(0.009)$ \\
\hline & $\mathrm{R}$ squared & 0.155 & 0.174 & 0.089 & 0.159 & & 0.289 \\
\hline & N. obs. & 1377 & 1387 & 1377 & 1387 & & 1385 \\
\hline \multirow[t]{8}{*}{ China } & R\&D & $0.078 * * *$ & $0.062 * * *$ & $0.072 * * *$ & $0.048 * * *$ & $0.054 * * *$ & $0.042 * * *$ \\
\hline & & $(0.015)$ & $(0.015)$ & $(0.014)$ & $(0.012)$ & $(0.015)$ & $(0.012)$ \\
\hline & New product line & 0.022 & 0.020 & $0.034 * *$ & $0.035 * * *$ & 0.018 & 0.020 \\
\hline & & $(0.016)$ & $(0.016)$ & $(0.015)$ & $(0.013)$ & $(0.018)$ & $(0.016)$ \\
\hline & Imported inputs dummy & -0.028 & $-0.060 * * *$ & -0.004 & $-0.023 *$ & 0.023 & 0.001 \\
\hline & & $(0.017)$ & $(0.016)$ & $(0.016)$ & $(0.014)$ & $(0.016)$ & $(0.014)$ \\
\hline & $\mathrm{R}$ squared & 0.279 & 0.281 & 0.308 & 0.347 & 0.329 & 0.325 \\
\hline & N. obs. & 899 & 902 & 899 & 902 & 899 & 902 \\
\hline
\end{tabular}

Notes: All regressions include industry and region dummies and dummies for the level of education of the plant manager. Robust standard errors in parenthesis. * represents significance at $10 \%$; * significance at $5 \%$; *** significance at $1 \%$.

Table 6. Skilled Labor Demand and Imported Inputs Share

\begin{tabular}{|c|c|c|c|c|c|c|c|}
\hline & Coefficients & $\begin{array}{c}\text { Wage } \\
\text { nonprod. }\end{array}$ & $\begin{array}{c}\text { Empl. } \\
\text { nonprod. }\end{array}$ & $\begin{array}{l}\text { Wage eng., } \\
\text { tech. and } \\
\text { man. occ. }\end{array}$ & $\begin{array}{l}\text { Empl. eng., } \\
\text { tech. and } \\
\text { man. occ. }\end{array}$ & $\begin{array}{c}\text { Wage some } \\
\text { college }\end{array}$ & $\begin{array}{l}\text { Empl. } \\
\text { some } \\
\text { college }\end{array}$ \\
\hline \multirow[t]{8}{*}{ Brazil } & $\mathrm{R} \& \mathrm{D}$ & 0.020 & $0.039 * * *$ & 0.004 & $0.020 * * *$ & & $0.020 * *$ \\
\hline & & $(0.013)$ & $(0.010)$ & $(0.012)$ & $(0.006)$ & & $(0.008)$ \\
\hline & New product line & 0.016 & $0.029 * * *$ & 0.005 & $0.014 * *$ & & $0.017 * * *$ \\
\hline & & $(0.014)$ & $(0.009)$ & $(0.012)$ & $(0.006)$ & & $(0.005)$ \\
\hline & Imported inputs share & 0.059 & 0.035 & $0.065 * *$ & $0.037 * *$ & & 0.018 \\
\hline & & $(0.037)$ & $(0.027)$ & $(0.031)$ & $(0.018)$ & & $(0.016)$ \\
\hline & R squared & 0.145 & 0.169 & 0.080 & 0.160 & & 0.279 \\
\hline & N. obs. & 1377 & 1387 & 1377 & 1387 & & 1385 \\
\hline \multirow[t]{8}{*}{ China } & $\mathrm{R} \& \mathrm{D}$ & $0.069 * * *$ & $0.050 * * *$ & $0.066 * * *$ & $0.041 * * *$ & $0.055 * * *$ & $0.043 * * *$ \\
\hline & & $(0.015)$ & $(0.015)$ & $(0.014)$ & $(0.012)$ & $(0.015)$ & $(0.012)$ \\
\hline & New product line & 0.022 & 0.020 & $0.033 * *$ & $0.035 * *$ & 0.019 & 0.021 \\
\hline & & $(0.016)$ & $(0.016)$ & $(0.015)$ & $(0.014)$ & $(0.018)$ & $(0.016)$ \\
\hline & Imported inputs share & $-0.107 * * *$ & $-0.131 * * *$ & $-0.064 * *$ & $-0.063 * * *$ & 0.015 & 0.005 \\
\hline & & $(0.028)$ & $(0.026)$ & $(0.026)$ & $(0.022)$ & $(0.027)$ & $(0.023)$ \\
\hline & R squared & 0.287 & 0.284 & 0.314 & 0.350 & 0.326 & 0.321 \\
\hline & N. obs. & 893 & 896 & 893 & 896 & 893 & 896 \\
\hline
\end{tabular}

Notes: All regressions include industry and region dummies and dummies for the level of education of the plant manager. Robust standard errors in parenthesis. * represents significance at $10 \% ; * *$ significance at $5 \%$; *** significance at $1 \%$. 
Table 7. Skilled Labor Demand and Exports Dummy

\begin{tabular}{|c|c|c|c|c|c|c|c|}
\hline & Coefficients & $\begin{array}{c}\text { Wage } \\
\text { nonprod. }\end{array}$ & $\begin{array}{c}\text { Empl. } \\
\text { nonprod. }\end{array}$ & $\begin{array}{l}\text { Wage eng., } \\
\text { tech. and } \\
\text { man. occ. }\end{array}$ & $\begin{array}{l}\text { Empl. eng., } \\
\text { tech. and } \\
\text { man. occ. }\end{array}$ & $\begin{array}{c}\text { Wage some } \\
\text { college }\end{array}$ & $\begin{array}{c}\text { Empl. } \\
\text { some } \\
\text { college }\end{array}$ \\
\hline \multirow[t]{6}{*}{ Brazil } & R\&D & 0.021 & $0.039 * * *$ & 0.004 & $0.020 * * *$ & & $0.020 * *$ \\
\hline & & $(0.013)$ & $(0.010)$ & $(0.012)$ & $(0.006)$ & & $(0.008)$ \\
\hline & New product line & 0.015 & $0.030 * * *$ & 0.004 & $0.014 * *$ & & $0.017 * * *$ \\
\hline & & $(0.014)$ & $(0.009)$ & $(0.012)$ & $(0.006)$ & & $(0.005)$ \\
\hline & $\mathrm{R}$ squared & 0.148 & 0.167 & 0.088 & 0.155 & & 0.279 \\
\hline & N. obs. & 1377 & 1387 & 1377 & 1387 & & 1385 \\
\hline \multirow[t]{5}{*}{ China } & R\&D & $0.076 * * *$ & $0.060 * * *$ & $0.069 * * *$ & $0.046 * * *$ & $0.052 * * *$ & $0.040 * * *$ \\
\hline & & $(0.015)$ & $(0.015)$ & $(0.014)$ & $(0.012)$ & $(0.015)$ & $(0.012)$ \\
\hline & New product line & 0.024 & 0.024 & $0.034 * *$ & $0.037 * * *$ & 0.017 & 0.020 \\
\hline & $\mathrm{R}$ squared & 0.283 & 0.286 & 0.313 & 0.355 & 0.328 & 0.327 \\
\hline & N. obs. & 899 & 902 & 899 & 902 & 899 & 902 \\
\hline
\end{tabular}

Notes: All regressions include industry and region dummies and dummies for the level of education of the plant manager. Robust standard errors in parenthesis. * represents significance at $10 \% ; * *$ significance at $5 \%$; *** significance at $1 \%$.

Table 8. Skilled Labor Demand and Exports Share

\begin{tabular}{|c|c|c|c|c|c|c|c|}
\hline & Coefficients & $\begin{array}{c}\text { Wage } \\
\text { nonprod. }\end{array}$ & $\begin{array}{c}\text { Empl. } \\
\text { nonprod. }\end{array}$ & $\begin{array}{l}\text { Wage eng., } \\
\text { tech. and } \\
\text { man. occ. }\end{array}$ & $\begin{array}{l}\text { Empl. eng., } \\
\text { tech. and } \\
\text { man. occ. }\end{array}$ & $\begin{array}{c}\text { Wage some } \\
\text { college }\end{array}$ & $\begin{array}{c}\text { Empl. } \\
\text { some } \\
\text { college }\end{array}$ \\
\hline \multirow{5}{*}{ Brazil } & & $(0.013)$ & $(0.010)$ & $(0.012)$ & $(0.006)$ & & $(0.008)$ \\
\hline & New product line & 0.017 & $0.030 * * *$ & 0.006 & $0.014 * *$ & & $0.017 * * *$ \\
\hline & & $(0.014)$ & $(0.009)$ & $(0.012)$ & $(0.006)$ & & $(0.005)$ \\
\hline & $\mathrm{R}$ squared & 0.142 & 0.171 & 0.073 & 0.155 & & 0.278 \\
\hline & N. obs. & 1377 & 1387 & 1377 & 1387 & & 1385 \\
\hline \multirow[t]{5}{*}{ China } & $\mathrm{R} \& \mathrm{D}$ & $0.058 * * *$ & $0.036 * *$ & $0.058 * * *$ & $0.032 * * *$ & $0.042 * * *$ & $0.032 * *$ \\
\hline & & $(0.015)$ & $(0.015)$ & $(0.014)$ & $(0.012)$ & $(0.015)$ & $(0.012)$ \\
\hline & New product line & 0.016 & 0.013 & $0.028 *$ & $0.030 * *$ & 0.013 & 0.016 \\
\hline & R squared & 0.311 & 0.332 & 0.325 & 0.373 & 0.337 & 0.337 \\
\hline & N. obs. & 899 & 902 & 899 & 902 & 899 & 902 \\
\hline
\end{tabular}

Notes: All regressions include industry and region dummies and dummies for the level of education of the plant manager. Robust standard errors in parenthesis. * represents significance at $10 \% ; * *$ significance at $5 \%$; *** significance at $1 \%$. 
Table 9. Skilled Labor Demand and Foreign Ownership Dummy

\begin{tabular}{|c|c|c|c|c|c|c|c|}
\hline & Coefficients & $\begin{array}{c}\text { Wage } \\
\text { nonprod. }\end{array}$ & $\begin{array}{c}\text { Empl. } \\
\text { nonprod. }\end{array}$ & $\begin{array}{l}\text { Wage eng., } \\
\text { tech. and } \\
\text { man. occ. }\end{array}$ & $\begin{array}{l}\text { Empl. eng., } \\
\text { tech. and } \\
\text { man. occ. }\end{array}$ & $\begin{array}{c}\text { Wage some } \\
\text { college }\end{array}$ & $\begin{array}{l}\text { Empl. } \\
\text { some } \\
\text { college }\end{array}$ \\
\hline \multirow[t]{8}{*}{ Brazil } & $\mathrm{R} \& \mathrm{D}$ & $0.022 *$ & $0.040 * * *$ & 0.006 & $0.021 * * *$ & & $0.020 * *$ \\
\hline & & $(0.013)$ & $(0.010)$ & $(0.012)$ & $(0.006)$ & & $(0.008)$ \\
\hline & New product line & 0.018 & $0.030 * * *$ & 0.007 & $0.015 * *$ & & $0.017 * * *$ \\
\hline & & $(0.014)$ & $(0.009)$ & $(0.012)$ & $(0.006)$ & & $(0.005)$ \\
\hline & FDI dummy & $0.124 * * *$ & $0.044 *$ & $0.128 * * *$ & $0.053 * * *$ & & $0.038 * *$ \\
\hline & & $(0.035)$ & $(0.027)$ & $(0.030)$ & $(0.019)$ & & $(0.018)$ \\
\hline & R squared & 0.156 & 0.170 & 0.097 & 0.165 & & 0.282 \\
\hline & N. obs. & 1377 & 1387 & 1377 & 1387 & & 1385 \\
\hline \multirow[t]{8}{*}{ China } & R\&D & $0.080 * * *$ & $0.064 * * *$ & $0.074 * * *$ & $0.050 * * *$ & $0.054 * * *$ & $0.043 * * *$ \\
\hline & & $(0.015)$ & $(0.015)$ & $(0.014)$ & $(0.012)$ & $(0.015)$ & $(0.012)$ \\
\hline & New product line & 0.025 & 0.023 & $0.036 * *$ & $0.038 * * *$ & 0.018 & 0.021 \\
\hline & & $(0.016)$ & $(0.016)$ & $(0.015)$ & $(0.014)$ & $(0.018)$ & $(0.016)$ \\
\hline & FDI dummy & $0.027 *$ & -0.004 & $0.047 * * *$ & $0.028 * *$ & $0.036 * *$ & $0.022 *$ \\
\hline & & $(0.016)$ & $(0.016)$ & $(0.015)$ & $(0.013)$ & $(0.014)$ & $(0.012)$ \\
\hline & $\mathrm{R}$ squared & 0.279 & 0.270 & 0.317 & 0.349 & 0.332 & 0.327 \\
\hline & N. obs. & 899 & 902 & 899 & 902 & 899 & 902 \\
\hline
\end{tabular}

Notes: All regressions include industry and region dummies and dummies for the level of education of the plant manager. Robust standard errors in parenthesis. * represents significance at $10 \% ; * *$ significance at $5 \% ; * * *$ significance at $1 \%$.

Table 10. Skilled Labor Demand and Foreign Ownership Share

\begin{tabular}{|c|c|c|c|c|c|c|c|}
\hline & Coefficients & $\begin{array}{c}\text { Wage } \\
\text { nonprod. }\end{array}$ & $\begin{array}{c}\text { Empl. } \\
\text { nonprod. }\end{array}$ & $\begin{array}{l}\text { Wage eng., } \\
\text { tech. and } \\
\text { man. occ. }\end{array}$ & $\begin{array}{l}\text { Empl. eng., } \\
\text { tech. and } \\
\text { man. occ. }\end{array}$ & $\begin{array}{c}\text { Wage some } \\
\text { college }\end{array}$ & $\begin{array}{c}\text { Empl. } \\
\text { some } \\
\text { college }\end{array}$ \\
\hline \multirow[t]{2}{*}{ Brazil } & R\&D & $0.023 *$ & $0.040 * * *$ & 0.007 & $0.021 * * *$ & & $0.020 * *$ \\
\hline & & $(0.013)$ & $(0.010)$ & $(0.012)$ & $(0.006)$ & & $(0.008)$ \\
\hline \multirow{2}{*}{\multicolumn{2}{|c|}{ with weigh New product line }} & 0.017 & $0.030 * * *$ & 0.006 & $0.015 * *$ & & $0.017 * * *$ \\
\hline & & $(0.014)$ & $(0.009)$ & $(0.012)$ & $(0.006)$ & & $(0.005)$ \\
\hline & FDI share & $0.151 * * *$ & $0.054 *$ & $0.146 * * *$ & $0.063 * * *$ & & $0.047 * *$ \\
\hline & & $(0.041)$ & $(0.033)$ & $(0.035)$ & $(0.024)$ & & $(0.021)$ \\
\hline & $\mathrm{R}$ squared & 0.158 & 0.1706 & 0.0959 & 0.166 & & 0.283 \\
\hline & N. obs. & 1377 & 1387 & 1377 & 1387 & & 1385 \\
\hline \multirow[t]{8}{*}{ China } & $\mathrm{R} \& \mathrm{D}$ & $0.081 * * *$ & $0.063 * * *$ & $0.075 * * *$ & $0.050 * * *$ & $0.055 * * *$ & $0.043 * * *$ \\
\hline & & $(0.015)$ & $(0.015)$ & $(0.014)$ & $(0.012)$ & $(0.015)$ & $(0.012)$ \\
\hline & New product line & 0.025 & 0.022 & $0.037 * *$ & $0.038 * * *$ & 0.019 & 0.021 \\
\hline & & $(0.016)$ & $(0.016)$ & $(0.015)$ & $(0.014)$ & $(0.018)$ & $(0.016)$ \\
\hline & FDI share & 0.035 & -0.027 & $0.065 * * *$ & 0.032 & $0.049 * *$ & 0.028 \\
\hline & & $(0.025)$ & $(0.025)$ & $(0.024)$ & $(0.021)$ & $(0.023)$ & $(0.019)$ \\
\hline & $\mathrm{R}$ squared & 0.278 & 0.271 & 0.315 & 0.347 & 0.331 & 0.326 \\
\hline & N. obs. & 899 & 902 & 899 & 902 & 899 & 902 \\
\hline
\end{tabular}

Notes: All regressions include industry and region dummies and dummies for the level of education of the plant manager. Robust standard errors in parenthesis. * represents significance at $10 \% ; * *$ significance at $5 \%$; *** significance at $1 \%$. 
Table 11. Skilled Labor Demand and Imported Inputs, Exports and FDI Dummies

\begin{tabular}{|c|c|c|c|c|c|c|c|}
\hline & Coefficients & $\begin{array}{c}\text { Wage } \\
\text { nonprod. }\end{array}$ & $\begin{array}{c}\text { Empl. } \\
\text { nonprod. }\end{array}$ & $\begin{array}{l}\text { Wage eng., } \\
\text { tech. and } \\
\text { man. occ. }\end{array}$ & $\begin{array}{c}\text { Empl. eng., } \\
\text { tech. and } \\
\text { man. occ. }\end{array}$ & $\begin{array}{l}\text { Wage } \\
\text { some } \\
\text { college }\end{array}$ & $\begin{array}{l}\text { Empl. } \\
\text { some } \\
\text { college }\end{array}$ \\
\hline \multirow[t]{12}{*}{ Brazil } & $R \& D$ & 0.020 & $0.038 * * *$ & 0.004 & $0.020 * * *$ & & $0.019 * *$ \\
\hline & & $(0.013)$ & $(0.010)$ & $(0.011)$ & $(0.006)$ & & $(0.008)$ \\
\hline & New product line & 0.014 & $0.029 * * *$ & 0.004 & $0.014 * *$ & & $0.016 * * *$ \\
\hline & & $(0.014)$ & $(0.009)$ & $(0.012)$ & $(0.006)$ & & $(0.005)$ \\
\hline & Imported Inputs dummy & $0.039 * * *$ & $0.023 * *$ & $0.033 * * *$ & $0.012 *$ & & $0.021 * *$ \\
\hline & & $(0.014)$ & $(0.010)$ & $(0.012)$ & $(0.006)$ & & $(0.009)$ \\
\hline & Exports dummy & $0.031 *$ & -0.004 & $0.041 * *$ & 0.007 & & 0.004 \\
\hline & & $(0.017)$ & $(0.012)$ & $(0.016)$ & $(0.009)$ & & $(0.010)$ \\
\hline & FDI dummy & $0.108 * * *$ & 0.040 & $0.112 * * *$ & $0.048 * * *$ & & $0.033 *$ \\
\hline & & $(0.034)$ & $(0.027)$ & $(0.029)$ & $(0.019)$ & & $(0.018)$ \\
\hline & $\mathrm{R}$ squared & 0.172 & 0.176 & 0.118 & 0.171 & & 0.292 \\
\hline & N. obs. & 1377 & 1387 & 1377 & 1387 & & 1385 \\
\hline \multirow[t]{12}{*}{ China } & $\mathrm{R} \& \mathrm{D}$ & $0.077 * * *$ & $0.060 * * *$ & $0.071 * * *$ & $0.047 * * *$ & $0.053 * * *$ & $0.041 * * *$ \\
\hline & & $(0.015)$ & $(0.015)$ & $(0.014)$ & $(0.012)$ & $(0.015)$ & $(0.012)$ \\
\hline & New product line & 0.025 & 0.022 & $0.037 * *$ & $0.038 * * *$ & 0.020 & 0.021 \\
\hline & & $(0.016)$ & $(0.016)$ & $(0.015)$ & $(0.013)$ & $(0.018)$ & $(0.016)$ \\
\hline & Imported Inputs dummy & -0.020 & $-0.042 * *$ & 0.000 & -0.014 & 0.026 & 0.006 \\
\hline & & $(0.019)$ & $(0.018)$ & $(0.018)$ & $(0.015)$ & $(0.018)$ & $(0.015)$ \\
\hline & Exports dummy & $-0.048 * * *$ & $-0.061 * * *$ & $-0.050 * * *$ & $-0.052 * * *$ & $-0.033 *$ & $-0.032 * *$ \\
\hline & & $(0.018)$ & $(0.019)$ & $(0.017)$ & $(0.016)$ & $(0.017)$ & $(0.015)$ \\
\hline & FDI dummy & $0.041 * *$ & 0.018 & $0.057 * * *$ & $0.042 * * *$ & $0.037 * *$ & $0.027 * *$ \\
\hline & & $(0.017)$ & $(0.017)$ & $(0.015)$ & $(0.013)$ & $(0.015)$ & $(0.012)$ \\
\hline & $\mathrm{R}$ squared & 0.289 & 0.291 & 0.325 & 0.362 & 0.336 & 0.331 \\
\hline & N. obs. & 899 & 902 & 899 & 902 & 899 & 902 \\
\hline
\end{tabular}

Note: All regressions include industry and region dummies and dummies for the level of education of the plant manager. Robust standard errors in parenthesis. * represents significance at $10 \% ; * *$ significance at $5 \%$; *** significance at $1 \%$. 
Table 12. Skilled Labor Demand and Imported Inputs, Exports and FDI Shares

\begin{tabular}{|c|c|c|c|c|c|c|c|}
\hline & Coefficients & $\begin{array}{c}\text { Wage } \\
\text { nonprod. } \\
\end{array}$ & $\begin{array}{l}\text { Empl. } \\
\text { nonprod. }\end{array}$ & $\begin{array}{l}\text { Wage eng., } \\
\text { tech. and } \\
\text { man. occ. }\end{array}$ & $\begin{array}{l}\text { Empl. eng., } \\
\text { tech. and } \\
\text { man. occ. }\end{array}$ & $\begin{array}{c}\text { Wage } \\
\text { some } \\
\text { college } \\
\end{array}$ & $\begin{array}{l}\text { Empl. } \\
\text { some } \\
\text { college } \\
\end{array}$ \\
\hline \multirow[t]{7}{*}{ Brazil } & $R \& D$ & $\begin{array}{c}0.022 * \\
(0.013)\end{array}$ & $\begin{array}{l}0.039 * * * \\
(0.010)\end{array}$ & $\begin{array}{r}0.006 \\
(0.012)\end{array}$ & $\begin{array}{l}0.020 \text { *** } \\
(0.006)\end{array}$ & & $\begin{array}{l}0.020 \text { ** } \\
(0.008)\end{array}$ \\
\hline & New product line & $\begin{array}{r}0.016 \\
(0.014)\end{array}$ & $\begin{array}{l}0.029 * * * \\
(0.009)\end{array}$ & $\begin{array}{r}0.006 \\
(0.012)\end{array}$ & $\begin{array}{l}0.014 * * \\
(0.006)\end{array}$ & & $\begin{array}{l}0.017 * * * \\
(0.005)\end{array}$ \\
\hline & Imported inputs share & $\begin{array}{r}0.040 \\
(0.034)\end{array}$ & $\begin{array}{r}0.027 \\
(0.026)\end{array}$ & $\begin{array}{r}0.047 \\
(0.029)\end{array}$ & $\begin{array}{l}0.029 * \\
(0.017)\end{array}$ & & $\begin{array}{r}0.012 \\
(0.016)\end{array}$ \\
\hline & Exports share & $\begin{array}{l}-0.052 * \\
(0.026)\end{array}$ & $\begin{array}{l}-0.076 * * * \\
(0.019)\end{array}$ & $\begin{array}{r}-0.033 \\
(0.026)\end{array}$ & $\begin{array}{l}-0.034 * * * \\
(0.012)\end{array}$ & & $\begin{array}{r}-0.021 \\
(0.014)\end{array}$ \\
\hline & FDI share & $\begin{array}{l}0.150 \text { *** } \\
(0.041)\end{array}$ & $\begin{array}{c}0.060 * \\
(0.031)\end{array}$ & $\begin{array}{l}0.141 * * * \\
(0.034)\end{array}$ & $\begin{array}{l}0.063 \text { *** } \\
(0.022)\end{array}$ & & $\begin{array}{l}0.047 * * \\
(0.020)\end{array}$ \\
\hline & $\mathrm{R}$ squared & 0.161 & 0.178 & 0.100 & 0.173 & & 0.284 \\
\hline & N. obs. & 1377 & 1387 & 1377 & 1387 & & 1385 \\
\hline \multirow[t]{7}{*}{ China } & $\mathrm{R} \& \mathrm{D}$ & $\begin{array}{l}0.057 \text { *** } \\
(0.015)\end{array}$ & $\begin{array}{l}0.032 \text { ** } \\
(0.015)\end{array}$ & $\begin{array}{l}0.059 * * * \\
(0.014)\end{array}$ & $\begin{array}{l}0.032 \text { *** } \\
(0.012)\end{array}$ & $\begin{array}{l}0.048 \text { *** } \\
(0.015)\end{array}$ & $\begin{array}{l}0.035 \text { *** } \\
(0.012)\end{array}$ \\
\hline & New product line & $\begin{array}{r}0.020 \\
(0.016)\end{array}$ & $\begin{array}{r}0.014 \\
(0.015)\end{array}$ & $\begin{array}{l}0.033 \text { ** } \\
(0.015)\end{array}$ & $\begin{array}{l}0.033 * * \\
(0.013)\end{array}$ & $\begin{array}{r}0.018 \\
(0.018)\end{array}$ & $\begin{array}{r}0.020 \\
(0.016)\end{array}$ \\
\hline & Imported inputs share & $\begin{array}{r}-0.051 \\
(0.032)\end{array}$ & $\begin{array}{r}-0.041 \\
(0.027)\end{array}$ & $\begin{array}{r}-0.033 \\
(0.029)\end{array}$ & $\begin{array}{l}-0.018 \\
(0.025)\end{array}$ & $\begin{array}{l}0.052 * \\
(0.030)\end{array}$ & $\begin{array}{l}0.043 * \\
(0.025)\end{array}$ \\
\hline & Exports share & $\begin{array}{l}-0.144 * * * \\
(0.026)\end{array}$ & $\begin{array}{l}-0.183 * * * \\
(0.023)\end{array}$ & $\begin{array}{l}-0.103 * * * \\
(0.024)\end{array}$ & $\begin{array}{l}-0.114 * * * \\
(0.021)\end{array}$ & $\begin{array}{l}-0.100 * * * \\
(0.023)\end{array}$ & $\begin{array}{l}-0.090 * * * \\
(0.018)\end{array}$ \\
\hline & FDI share & $\begin{array}{l}0.074 \text { *** } \\
(0.025)\end{array}$ & $\begin{array}{r}0.016 \\
(0.023)\end{array}$ & $\begin{array}{l}0.094 * * * \\
(0.024)\end{array}$ & $\begin{array}{l}0.059 * * * \\
(0.020)\end{array}$ & $\begin{array}{l}0.059 * * \\
(0.024)\end{array}$ & $\begin{array}{l}0.038 * \\
(0.020)\end{array}$ \\
\hline & R squared & 0.320 & 0.331 & 0.341 & 0.378 & 0.345 & 0.340 \\
\hline & N. obs. & 893 & 896 & 893 & 896 & 893 & 896 \\
\hline
\end{tabular}

Note: All regressions include industry and region dummies and dummies for the level of education of the plant manager. Robust standard errors in parenthesis. * represents significance at $10 \% ; * *$ significance at $5 \%$; *** significance at $1 \%$. 
Table 13. Relative Wages, Relative Employment and Imported Inputs Share

\begin{tabular}{|c|c|c|c|c|c|c|c|}
\hline & Coefficients & nonprod. & Rel. Empl. & $\begin{array}{l}\text { Rel. Wage } \\
\text { eng., tech. } \\
\text { and man. } \\
\text { occ. }\end{array}$ & $\begin{array}{l}\text { Rel. Empl. } \\
\text { eng., tech. } \\
\text { and man. } \\
\text { occ. }\end{array}$ & $\begin{array}{l}\text { Rel. Wage } \\
\text { some } \\
\text { college } \\
\end{array}$ & $\begin{array}{l}\text { Rel. Empl. } \\
\text { some } \\
\text { college } \\
\end{array}$ \\
\hline \multirow[t]{5}{*}{ Brazil } & $\mathrm{R} \& \mathrm{D}$ & $\begin{array}{c}-0.085 * \\
(0.050)\end{array}$ & $\begin{array}{c}0.262 \text { *** } \\
(0.063)\end{array}$ & $\begin{array}{c}-0.112 * \\
(0.058)\end{array}$ & $\begin{array}{c}0.206 \text { *** } \\
(0.057)\end{array}$ & & $\begin{array}{r}0.102 \\
(0.089)\end{array}$ \\
\hline & New product line & $\begin{array}{l}-0.165 * * * \\
(0.054)\end{array}$ & $\begin{array}{l}0.193 * * * \\
(0.065)\end{array}$ & $\begin{array}{l}-0.139 * * \\
(0.057)\end{array}$ & $\begin{array}{l}0.159 * * * \\
(0.059)\end{array}$ & & $\begin{array}{r}0.113 \\
(0.079)\end{array}$ \\
\hline & Imported inputs share & $\begin{array}{l}0.201 * \\
(0.121)\end{array}$ & $\begin{array}{r}0.195 \\
(0.168)\end{array}$ & $\begin{array}{l}0.227 * \\
(0.137)\end{array}$ & $\begin{array}{c}0.276 * \\
(0.143)\end{array}$ & & $\begin{array}{l}0.458 * * \\
(0.197)\end{array}$ \\
\hline & $\mathrm{R}$ squared & 0.111 & 0.189 & 0.179 & 0.230 & & 0.162 \\
\hline & N. obs. & 1290 & 1385 & 1287 & 1387 & & 1180 \\
\hline \multirow[t]{5}{*}{ China } & R\&D & $\begin{array}{r}0.005 \\
(0.042)\end{array}$ & $\begin{array}{l}0.333 * * * \\
(0.074)\end{array}$ & $\begin{array}{r}0.042 \\
(0.038)\end{array}$ & $\begin{array}{l}0.306 * * * \\
(0.063)\end{array}$ & $\begin{array}{r}0.006 \\
(0.070)\end{array}$ & $\begin{array}{l}0.474 * * * \\
(0.164)\end{array}$ \\
\hline & New product line & $\begin{array}{r}0.006 \\
(0.043)\end{array}$ & $\begin{array}{r}0.040 \\
(0.073)\end{array}$ & $\begin{array}{r}-0.017 \\
(0.040)\end{array}$ & $\begin{array}{l}0.216 * * * \\
(0.071)\end{array}$ & $\begin{array}{r}-0.062 \\
(0.070)\end{array}$ & $\begin{array}{r}0.101 \\
(0.174)\end{array}$ \\
\hline & Imported inputs share & $\begin{array}{l}0.120 * \\
(0.070)\end{array}$ & $\begin{array}{l}-0.632 * * * \\
(0.141)\end{array}$ & $\begin{array}{l}0.156 \text { ** } \\
(0.061)\end{array}$ & $\begin{array}{l}-0.383 * * * \\
(0.131)\end{array}$ & $\begin{array}{r}0.060 \\
(0.108)\end{array}$ & $\begin{array}{r}0.192 \\
(0.356)\end{array}$ \\
\hline & $\mathrm{R}$ squared & 0.102 & 0.238 & 0.082 & 0.337 & 0.127 & 0.336 \\
\hline & N. obs. & 807 & 864 & 822 & 883 & 276 & 296 \\
\hline
\end{tabular}

Note: All regressions include industry and region dummies and dummies for the level of education of the plant manager. Robust standard errors in parenthesis. * represents significance at $10 \%$; * significance at 5\%; *** significance at $1 \%$.

Table 14. Relative Wages, Relative Employment and Exports Share

\begin{tabular}{|c|c|c|c|c|c|c|c|}
\hline & Coefficients & nonprod. & Rel. Empl. & $\begin{array}{l}\text { Rel. Wage } \\
\text { eng., tech. } \\
\text { and man. } \\
\text { occ. }\end{array}$ & $\begin{array}{l}\text { Rel. Empl. } \\
\text { eng., tech. } \\
\text { and man. } \\
\text { occ. }\end{array}$ & $\begin{array}{l}\text { Rel. Wage } \\
\text { some } \\
\text { college }\end{array}$ & $\begin{array}{l}\text { Rel. Empl. } \\
\text { some } \\
\text { college }\end{array}$ \\
\hline \multirow[t]{8}{*}{ Brazil } & $\mathrm{R} \& \mathrm{D}$ & -0.078 & $0.256 * * *$ & $-0.105 *$ & $0.202 * * *$ & & 0.107 \\
\hline & & $(0.050)$ & $(0.063)$ & $(0.058)$ & $(0.057)$ & & $(0.089)$ \\
\hline & New product line & $-0.162 * * *$ & $0.194 * * *$ & $-0.136 * *$ & $0.161 * * *$ & & 0.118 \\
\hline & & $(0.055)$ & $(0.064)$ & $(0.057)$ & $(0.058)$ & & $(0.079)$ \\
\hline & Exports share & $0.271 *$ & $-0.405 * * *$ & 0.247 & $-0.337 * *$ & & -0.136 \\
\hline & & $(0.148)$ & $(0.149)$ & $(0.186)$ & $(0.153)$ & & $(0.167)$ \\
\hline & $\mathrm{R}$ squared & 0.109 & 0.187 & 0.176 & 0.227 & & 0.157 \\
\hline & N. obs. & 1290 & 1385 & 1287 & 1387 & & 1180 \\
\hline \multirow[t]{8}{*}{ China } & $\mathrm{R} \& \mathrm{D}$ & 0.021 & $0.273 * * *$ & 0.045 & $0.252 * * *$ & 0.027 & $0.276 *$ \\
\hline & & $(0.042)$ & $(0.072)$ & $(0.038)$ & $(0.061)$ & $(0.071)$ & $(0.157)$ \\
\hline & New product line & 0.016 & 0.002 & -0.011 & $0.188 * * *$ & -0.063 & 0.101 \\
\hline & & $(0.042)$ & $(0.070)$ & $(0.040)$ & $(0.068)$ & $(0.069)$ & $(0.170)$ \\
\hline & Exports share & $0.211 * * *$ & $-0.906 * * *$ & $0.159 * * *$ & $-0.669 * * *$ & $0.186 *$ & $-1.046 * * *$ \\
\hline & & $(0.056)$ & $(0.107)$ & $(0.053)$ & $(0.095)$ & $(0.097)$ & $(0.267)$ \\
\hline & $\mathrm{R}$ squared & 0.114 & 0.288 & 0.086 & 0.369 & 0.138 & 0.375 \\
\hline & N. obs. & 812 & 870 & 827 & 889 & 279 & 299 \\
\hline
\end{tabular}

Note: All regressions include industry and region dummies and dummies for the level of education of the plant manager. Robust standard errors in parenthesis. * represents significance at $10 \% ; * *$ significance at $5 \%$; *** significance at $1 \%$. 
Table 15. Relative Wages, Relative Employment and Foreign Ownership Share

\begin{tabular}{|c|c|c|c|c|c|c|c|}
\hline & Coefficients & nonprod. & Rel. Empl. & $\begin{array}{l}\text { Rel. Wage } \\
\text { eng., tech. } \\
\text { and man. } \\
\text { occ. }\end{array}$ & $\begin{array}{l}\text { Rel. Empl. } \\
\text { eng., tech. } \\
\text { and man. } \\
\text { occ. }\end{array}$ & $\begin{array}{c}\text { Rel. Wage } \\
\text { some } \\
\text { college }\end{array}$ & $\begin{array}{l}\text { Rel. Empl. } \\
\text { some } \\
\text { college }\end{array}$ \\
\hline \multirow[t]{8}{*}{ Brazil } & R\&D & -0.081 & $0.269 * * *$ & $-0.108 *$ & $0.218 * * *$ & & 0.119 \\
\hline & & $(0.050)$ & $(0.063)$ & $(0.058)$ & $(0.057)$ & & $(0.088)$ \\
\hline & New product line & $-0.163 * * *$ & $0.196 * * *$ & $-0.136 * *$ & $0.163 * * *$ & & 0.119 \\
\hline & & $(0.055)$ & $(0.064)$ & $(0.057)$ & $(0.057)$ & & $(0.078)$ \\
\hline & FDI share & 0.200 & $0.338 * *$ & 0.165 & $0.638 * * *$ & & $0.560 * * *$ \\
\hline & & $(0.131)$ & $(0.157)$ & $(0.169)$ & $(0.192)$ & & $(0.187)$ \\
\hline & $\mathrm{R}$ squared & 0.109 & 0.190 & 0.177 & 0.239 & & 0.164 \\
\hline & N. obs. & 1290 & 1385 & 1287 & 1387 & & 1180 \\
\hline \multirow[t]{8}{*}{ China } & $\mathrm{R} \& \mathrm{D}$ & 0.004 & $0.397 * * *$ & 0.033 & $0.358 * * *$ & 0.020 & $0.466 * * *$ \\
\hline & & $(0.040)$ & $(0.073)$ & $(0.036)$ & $(0.061)$ & $(0.068)$ & $(0.161)$ \\
\hline & New product line & 0.021 & 0.038 & -0.005 & $0.230 * * *$ & -0.050 & 0.092 \\
\hline & & $(0.043)$ & $(0.073)$ & $(0.040)$ & $(0.071)$ & $(0.068)$ & $(0.174)$ \\
\hline & FDI share & $0.282 * * *$ & $-0.251 * *$ & $0.227 * * *$ & 0.113 & $0.243 * *$ & 0.229 \\
\hline & & $(0.067)$ & $(0.125)$ & $(0.059)$ & $(0.119)$ & $(0.107)$ & $(0.268)$ \\
\hline & $\mathrm{R}$ squared & 0.123 & 0.227 & 0.094 & 0.331 & 0.144 & 0.340 \\
\hline & N. obs. & 812 & 870 & 827 & 889 & 279 & 299 \\
\hline
\end{tabular}

Notes: All regressions include industry and region dummies and dummies for the level of education of the plant manager. Robust standard errors in parenthesis. * represents significance at $10 \%$;* significance at 5\%; *** significance at $1 \%$.

Table 16. Skilled Labor Demand and Imported Inputs Share: Differential Effects in Industries with Comparative Advantage

\begin{tabular}{|c|c|c|c|c|c|c|c|}
\hline & Coefficients & $\begin{array}{c}\text { Wage } \\
\text { nonprod. }\end{array}$ & $\begin{array}{c}\text { Empl. } \\
\text { nonprod. }\end{array}$ & $\begin{array}{l}\text { Wage eng., } \\
\text { tech. and } \\
\text { man. occ. }\end{array}$ & $\begin{array}{l}\text { Empl. eng., } \\
\text { tech. and } \\
\text { man. occ. }\end{array}$ & $\begin{array}{c}\text { Wage some } \\
\text { college }\end{array}$ & $\begin{array}{c}\text { Empl. } \\
\text { some } \\
\text { college }\end{array}$ \\
\hline \multirow[t]{10}{*}{ Brazil } & $\mathrm{R} \& \mathrm{D}$ & 0.020 & $0.039 * * *$ & 0.004 & $0.020 * * *$ & & $0.020 * *$ \\
\hline & & $(0.013)$ & $(0.010)$ & $(0.012)$ & $(0.006)$ & & $(0.008)$ \\
\hline & New product line & 0.016 & $0.029 * * *$ & 0.005 & $0.014 * *$ & & $0.017 * * *$ \\
\hline & & $(0.014)$ & $(0.009)$ & $(0.012)$ & $(0.006)$ & & $(0.005)$ \\
\hline & Imp. Inputs Share & 0.060 & 0.033 & $0.069 * *$ & $0.040 * *$ & & 0.013 \\
\hline & & $(0.039)$ & $(0.029)$ & $(0.034)$ & $(0.020)$ & & $(0.017)$ \\
\hline & Imp. I.* Comp. Adv. & -0.011 & 0.020 & -0.059 & -0.046 & & 0.063 \\
\hline & & $(0.098)$ & $(0.076)$ & $(0.057)$ & $(0.033)$ & & $(0.052)$ \\
\hline & $\mathrm{R}$ squared & 0.145 & 0.169 & 0.081 & 0.161 & & 0.280 \\
\hline & N. obs. & 1377 & 1387 & 1377 & 1387 & & 1385 \\
\hline \multirow[t]{10}{*}{ China } & R\&D & $0.069 * * *$ & $0.050 * * *$ & $0.066 * * *$ & $0.041 * * *$ & $0.055 * * *$ & $0.043 * * *$ \\
\hline & & $(0.015)$ & $(0.015)$ & $(0.014)$ & $(0.012)$ & $(0.015)$ & $(0.012)$ \\
\hline & New product line & 0.023 & 0.021 & $0.033 * *$ & $0.035 * * *$ & 0.019 & 0.022 \\
\hline & & $(0.016)$ & $(0.016)$ & $(0.015)$ & $(0.014)$ & $(0.018)$ & $(0.016)$ \\
\hline & Imp. Inputs Share & -0.047 & $-0.092 * * *$ & -0.015 & -0.041 & 0.040 & 0.030 \\
\hline & & $(0.038)$ & $(0.033)$ & $(0.033)$ & $(0.028)$ & $(0.040)$ & $(0.033)$ \\
\hline & Imp. I.* Comp. Adv. & $-0.122 * * *$ & $-0.080 *$ & $-0.099 * *$ & -0.045 & -0.051 & -0.051 \\
\hline & & $(0.047)$ & $(0.044)$ & $(0.043)$ & $(0.037)$ & $(0.048)$ & $(0.040)$ \\
\hline & $\mathrm{R}$ squared & 0.292 & 0.286 & 0.318 & 0.350 & 0.327 & 0.323 \\
\hline & N. obs. & 893 & 896 & 893 & 896 & 893 & 896 \\
\hline
\end{tabular}

Notes: All regressions include industry and region dummies and dummies for the level of education of the plant manager. Robust standard errors in parenthesis. * represents significance at 10\%; ** significance at 5\%; *** significance at $1 \%$. Comp. Adv. is a dummy variable for industries with revealed comparative advantage indexes larger than 1. 
Table 17. Skilled Labor Demand and Exports Share: Differential Effects in Industries with Comparative Advantage

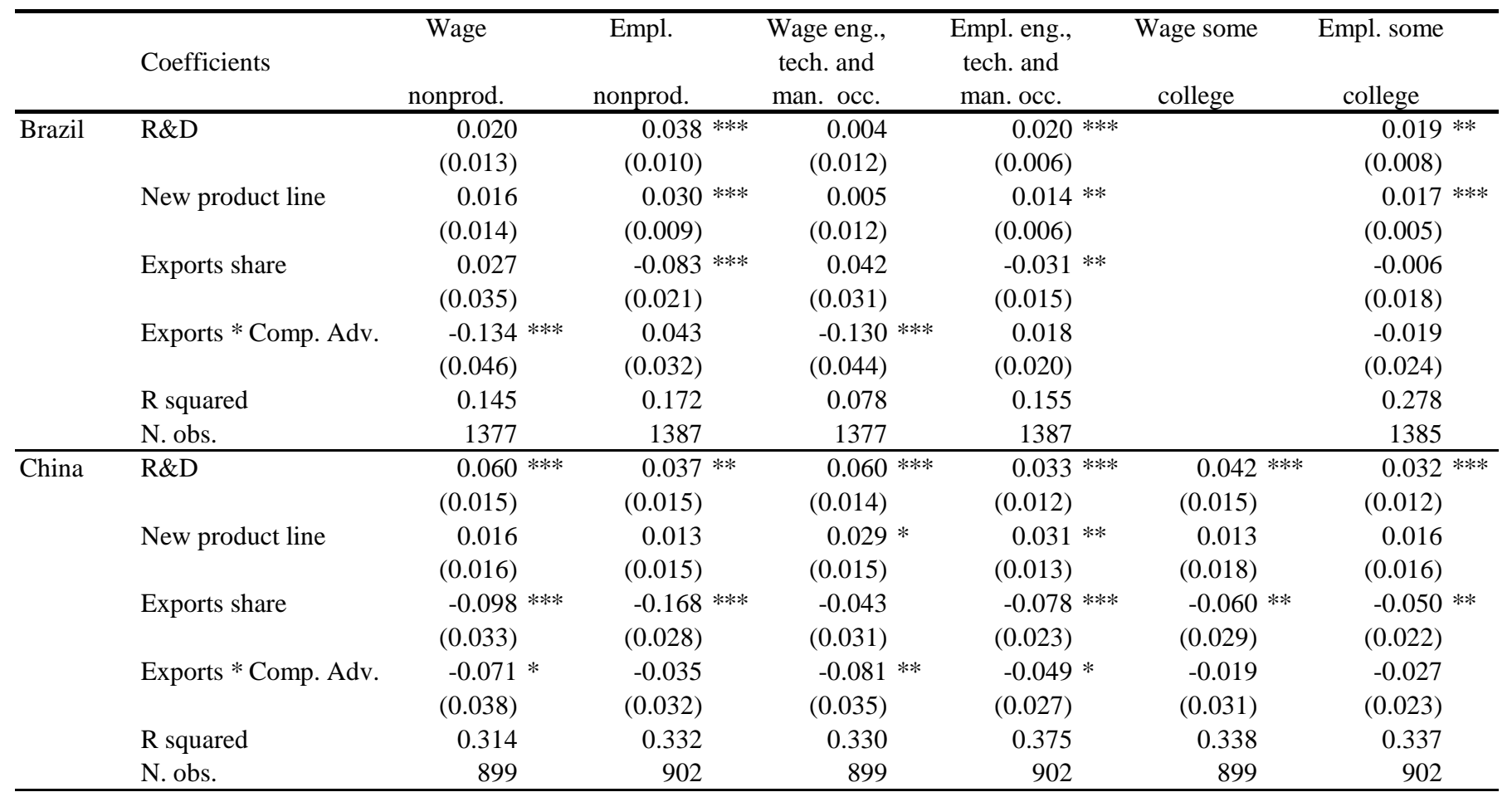

Notes: All regressions include industry and region dummies and dummies for the level of education of the plant manager. Robust standard errors in parenthesis. * represents significance at $10 \%$; ** significance at $5 \%$; *** significance at $1 \%$. Comp. Adv. is a dummy variable for industries with revealed comparative advantage indexes larger than 1.

Table 18. Skilled Labor Demand and FDI Share: Differential Effects in Industries with Comparative Advantage

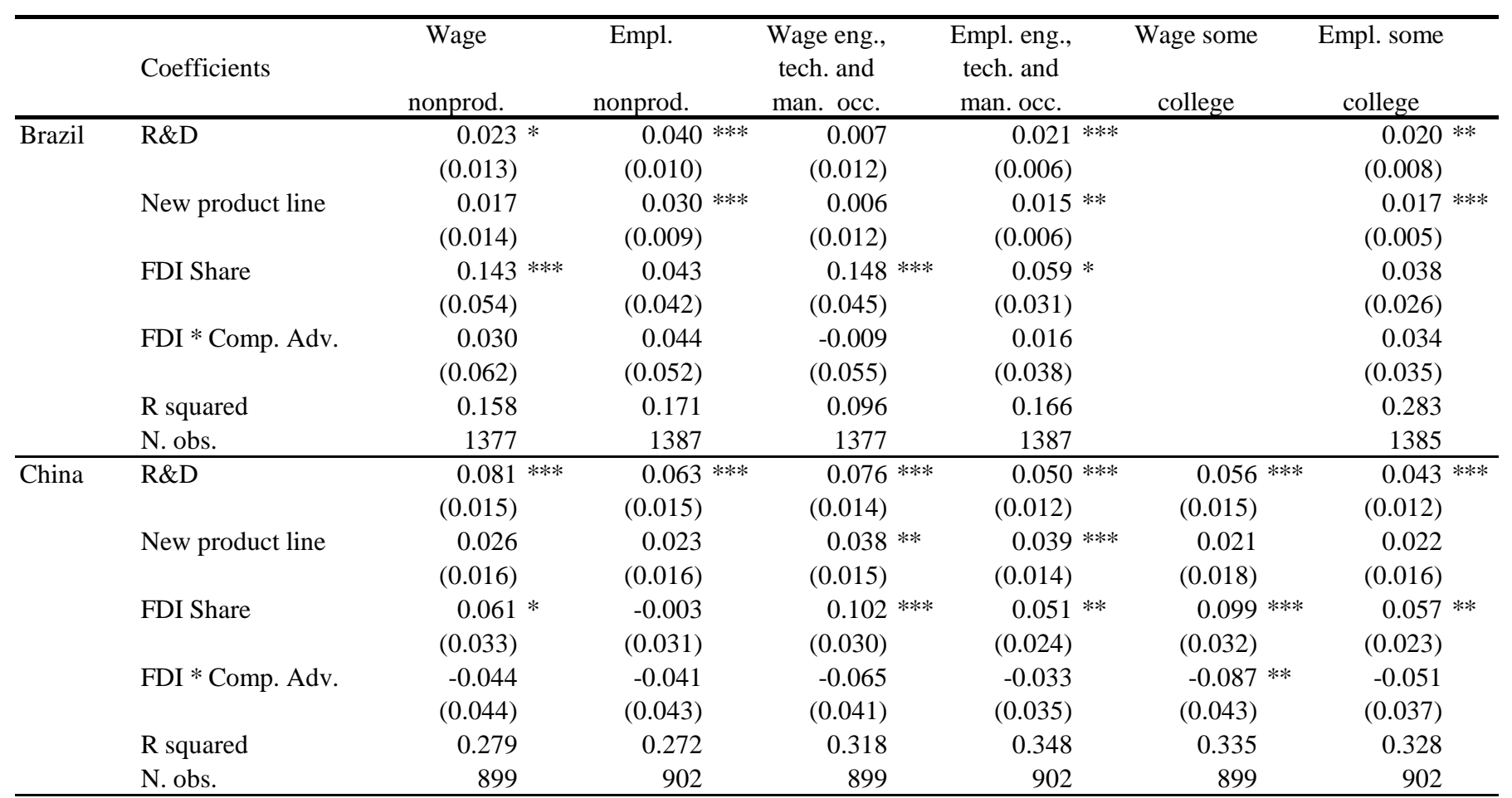

Notes: All regressions include industry and region dummies and dummies for the level of education of the plant manager. Robust standard errors in parenthesis. * represents significance at $10 \%$; ** significance at $5 \%$; *** significance at $1 \%$. Comp. Adv. is a dummy variable for industries with revealed comparative advantage indexes larger than 1. 
Table 19. Skilled Labor Demand and Imported Inputs Share: Instrumental Variables Estimates

\begin{tabular}{|c|c|c|c|c|c|c|c|}
\hline & Coefficients & $\begin{array}{c}\text { Wage } \\
\text { nonprod. }\end{array}$ & $\begin{array}{l}\text { Empl. } \\
\text { nonprod. }\end{array}$ & $\begin{array}{l}\text { Wage eng., } \\
\text { tech. and } \\
\text { man. occ. }\end{array}$ & $\begin{array}{l}\text { Empl. eng., } \\
\text { tech. and } \\
\text { man. occ. }\end{array}$ & $\begin{array}{c}\text { Wage some } \\
\text { college } \\
\end{array}$ & $\begin{array}{c}\text { Empl. some } \\
\text { college }\end{array}$ \\
\hline \multirow[t]{10}{*}{ Brazil } & \multirow[t]{2}{*}{$R \& D$} & 0.016 & $0.036 * * *$ & 0.000 & $0.018 * *$ & & $0.019 * *$ \\
\hline & & $(0.017)$ & $(0.012)$ & $(0.014)$ & $(0.008)$ & & $(0.009)$ \\
\hline & \multirow[t]{2}{*}{ New product line } & 0.008 & $0.024 * *$ & -0.002 & 0.011 & & $0.016 * * *$ \\
\hline & & $(0.018)$ & $(0.011)$ & $(0.015)$ & $(0.008)$ & & $(0.006)$ \\
\hline & \multirow[t]{2}{*}{ Imported inputs share } & $0.691 * * *$ & $0.356 * * *$ & $0.577 * * *$ & $0.279 * * *$ & & 0.136 \\
\hline & & $(0.180)$ & $(0.101)$ & $(0.163)$ & $(0.066)$ & & $(0.096)$ \\
\hline & Endogeneity test: p.v.(a) & 0.000 & 0.041 & 0.000 & 0.022 & & 0.186 \\
\hline & First stage $F$ test: p.v.(b) & 0.084 & 0.086 & 0.084 & 0.086 & & 0.077 \\
\hline & Hansen J test: p.v.(c) & 0.985 & 0.684 & 0.661 & 0.616 & & 0.581 \\
\hline & N. obs. & 1379 & 1389 & 1379 & 1389 & & 1387 \\
\hline \multirow[t]{10}{*}{ China } & \multirow[t]{2}{*}{$\mathrm{R} \& \mathrm{D}$} & $0.050 * * *$ & $0.035 *$ & $0.047 * * *$ & $0.025 *$ & $0.042 * *$ & $0.036 * *$ \\
\hline & & $(0.019)$ & $(0.019)$ & $(0.018)$ & $(0.015)$ & $(0.018)$ & $(0.014)$ \\
\hline & \multirow[t]{2}{*}{ New product line } & 0.015 & 0.017 & 0.026 & $0.032 * *$ & 0.014 & 0.019 \\
\hline & & $(0.018)$ & $(0.017)$ & $(0.017)$ & $(0.014)$ & $(0.019)$ & $(0.016)$ \\
\hline & \multirow[t]{2}{*}{ Imported inputs share } & $-0.301 * * *$ & $-0.279 * *$ & $-0.255 * *$ & $-0.209 * *$ & -0.126 & -0.067 \\
\hline & & $(0.116)$ & $(0.109)$ & $(0.106)$ & $(0.088)$ & $(0.104)$ & $(0.085)$ \\
\hline & Endogeneity test: p.v.(a) & 0.067 & 0.141 & 0.046 & 0.073 & 0.146 & 0.373 \\
\hline & First stage $\mathrm{F}$ test: p.v.(b) & 0.000 & 0.000 & 0.000 & 0.000 & 0.000 & 0.000 \\
\hline & Hansen J test: p.v.(c) & 0.800 & 0.639 & 0.940 & 0.248 & 0.835 & 0.582 \\
\hline & N. obs. & 886 & 889 & 886 & 889 & 886 & 889 \\
\hline
\end{tabular}

Notes: All regressions include industry and region dummies and dummies for the level of education of the plant manager. Robust standard errors in parenthesis. * represents significance at 10\%; ** significance at 5\%; *** significance at $1 \%$. The imported input share is assumed endogenous. In Brazil, the excluded instruments are industry-region average of foreign capital ownership, and industry export and import penetration rates. In China, the excluded instruments are industry-region averages of intermediate inputs import shares, government capital ownership and the fraction of firms that have been restructured into shareholding companies. * represents significance at 10\%; ** significance at 5\%; *** significance at $1 \%$. (a) p. value of test of significance of residual(s) of first stage regression(s) in original model. (b) p. value of test of joint significance of excluded instruments in first stage regression. (c) p. value of Hansen J test of overidentifying restrictions.

Table 20. Skilled Labor Demand and Exports Share: Instrumental Variables Estimates

\begin{tabular}{|c|c|c|c|c|c|c|c|}
\hline & Coefficients & $\begin{array}{c}\text { Wage } \\
\text { nonprod. }\end{array}$ & $\begin{array}{c}\text { Empl. } \\
\text { nonprod. }\end{array}$ & $\begin{array}{l}\text { Wage eng., } \\
\text { tech. and } \\
\text { man. occ. }\end{array}$ & $\begin{array}{l}\text { Empl. eng., } \\
\text { tech. and } \\
\text { man. occ. }\end{array}$ & $\begin{array}{c}\text { Wage some } \\
\text { college } \\
\end{array}$ & $\begin{array}{c}\text { Empl. some } \\
\text { college } \\
\end{array}$ \\
\hline \multirow[t]{10}{*}{ Brazil } & $R \& D$ & 0.018 & $0.040 * * *$ & 0.001 & $0.020 * * *$ & & $0.022 * *$ \\
\hline & & $(0.014)$ & $(0.010)$ & $(0.012)$ & $(0.007)$ & & $(0.008)$ \\
\hline & New product line & 0.017 & $0.029 * * *$ & 0.006 & $0.015 * *$ & & $0.018 * * *$ \\
\hline & & $(0.014)$ & $(0.009)$ & $(0.012)$ & $(0.006)$ & & $(0.005)$ \\
\hline & Export share & -0.161 & 0.051 & -0.172 & -0.002 & & 0.098 \\
\hline & & $(0.116)$ & $(0.095)$ & $(0.107)$ & $(0.060)$ & & $(0.078)$ \\
\hline & Endogeneity test: p.v.(a) & 0.231 & 0.187 & 0.104 & 0.704 & & 0.127 \\
\hline & First stage $F$ test: p.v.(b) & 0.000 & 0.000 & 0.000 & 0.000 & & 0.000 \\
\hline & Hansen J test: p.v.(c) & 0.331 & 0.649 & 0.332 & 0.196 & & 0.559 \\
\hline & N. obs. & 1379 & 1389 & 1379 & 1389 & & 1387 \\
\hline \multirow[t]{10}{*}{ China } & $\mathrm{R} \& \mathrm{D}$ & $0.053 * * *$ & $0.039 * *$ & $0.050 * * *$ & $0.031 * *$ & $0.031 *$ & $0.028 * *$ \\
\hline & & $(0.018)$ & $(0.017)$ & $(0.016)$ & $(0.013)$ & $(0.018)$ & $(0.014)$ \\
\hline & New product line & 0.011 & 0.014 & 0.024 & $0.031 * *$ & 0.007 & 0.014 \\
\hline & & $(0.016)$ & $(0.016)$ & $(0.016)$ & $(0.014)$ & $(0.019)$ & $(0.016)$ \\
\hline & Export share & $-0.188 * * *$ & $-0.173 * * *$ & $-0.154 * * *$ & $-0.114 * *$ & $-0.156 * *$ & $-0.095 *$ \\
\hline & & $(0.064)$ & $(0.060)$ & $(0.059)$ & $(0.047)$ & $(0.063)$ & $(0.051)$ \\
\hline & Endogeneity test: p.v.(a) & 0.499 & 0.757 & 0.327 & 0.938 & 0.156 & 0.572 \\
\hline & First stage $F$ test: p.v.(b) & 0.000 & 0.000 & 0.000 & 0.000 & 0.000 & 0.000 \\
\hline & Hansen J test: p.v.(c) & 0.522 & 0.424 & 0.770 & 0.253 & 0.849 & 0.616 \\
\hline & N. obs. & 892 & 895 & 892 & 895 & 892 & 895 \\
\hline
\end{tabular}

Note: All regressions include industry and region dummies and dummies for the level of education of the plant manager. Robust standard errors in parenthesis.

$*$ represents significance at $10 \%$; ** significance at $5 \%$; *** significance at $1 \%$. The export share is assumed endogenous. In Brazil, the excluded instruments are the fraction of exporters per industry-region and industry tariff and import penetration rates. In China, the excluded instruments are industry-region averages of export shares, government capital ownership and the fraction of firms that have been restructured into shareholding companies. $*$ represents significance at $10 \%$; $* *$ significance at $5 \%$; $* * *$ significance at $1 \%$. (a) p. value of test of significance of residual(s) of first stage regression(s) in original model. (b) p. value of test of joint significance of excluded instruments in first stage regression. (c) p. value of Hansen J test of overidentifying restrictions. 
Table 21. Skilled Labor Demand and FDI Share: Instrumental Variables Estimates

\begin{tabular}{|c|c|c|c|c|c|c|c|}
\hline & Coefficients & $\begin{array}{c}\text { Wage } \\
\text { nonprod. } \\
\end{array}$ & $\begin{array}{l}\text { Empl. } \\
\text { nonprod. }\end{array}$ & $\begin{array}{l}\text { Wage eng., } \\
\text { tech. and } \\
\text { man. occ. }\end{array}$ & $\begin{array}{l}\text { Empl. eng., } \\
\text { tech. and } \\
\text { man. occ. }\end{array}$ & $\begin{array}{c}\text { Wage some } \\
\text { college } \\
\end{array}$ & $\begin{array}{l}\text { Empl. } \\
\text { some } \\
\text { college }\end{array}$ \\
\hline \multirow[t]{10}{*}{ Brazil } & R\&D & $0.027 *$ & 0.042 *** & 0.008 & 0.023 *** & & $0.022 * * *$ \\
\hline & & $(0.014)$ & $(0.010)$ & $(0.012)$ & $(0.007)$ & & $(0.008)$ \\
\hline & New product line & 0.018 & $0.029 * * *$ & 0.007 & $0.015 * * *$ & & $0.018 * * *$ \\
\hline & & $(0.014)$ & $(0.009)$ & $(0.012)$ & $(0.006)$ & & $(0.005)$ \\
\hline & FDI share & $0.364 * * *$ & $0.228 * *$ & $0.258 * *$ & $0.178 * *$ & & 0.121 \\
\hline & & $(0.120)$ & $(0.099)$ & $(0.124)$ & $(0.071)$ & & $(0.079)$ \\
\hline & Endogeneity test: p.v.(a) & 0.117 & 0.109 & 0.390 & 0.114 & & 0.278 \\
\hline & First stage $\mathrm{F}$ test: p.v.(b) & 0.002 & 0.003 & 0.002 & 0.003 & & 0.002 \\
\hline & Hansen J test: p.v.(c) & 0.379 & 0.997 & 0.351 & 0.587 & & 0.991 \\
\hline & N. obs. & 1379 & 1389 & 1379 & 1389 & & 1387 \\
\hline \multirow[t]{10}{*}{ China } & R\&D & $0.059 * * *$ & $0.040 * *$ & $0.061 * * *$ & $0.031 * *$ & $0.051 * * *$ & $0.039 * * *$ \\
\hline & & $(0.020)$ & $(0.020)$ & $(0.017)$ & $(0.016)$ & $(0.016)$ & $(0.013)$ \\
\hline & New product line & 0.002 & 0.001 & 0.022 & 0.023 & 0.014 & 0.016 \\
\hline & & $(0.021)$ & $(0.020)$ & $(0.018)$ & $(0.016)$ & $(0.020)$ & $(0.017)$ \\
\hline & FDI share & $-0.392 * *$ & $-0.444 * * *$ & -0.212 & $-0.292 * *$ & -0.040 & -0.056 \\
\hline & & $(0.174)$ & $(0.170)$ & $(0.152)$ & $(0.136)$ & $(0.137)$ & $(0.117)$ \\
\hline & Endogeneity test: p.v.(a) & 0.003 & 0.004 & 0.041 & 0.006 & 0.502 & 0.460 \\
\hline & First stage $F$ test: p.v.(b) & 0.000 & 0.000 & 0.000 & 0.000 & 0.000 & 0.000 \\
\hline & Hansen J test: p.v.(c) & 0.746 & 0.646 & 0.792 & 0.333 & 0.886 & 0.636 \\
\hline & N. obs. & 892 & 895 & 892 & 895 & 892 & 895 \\
\hline
\end{tabular}

Notes: All regressions include industry and region dummies and dummies for the level of education of the plant manager. Robust standard errors in parenthesis. * represents significance at 10\%; ** significance at 5\%; *** significance at $1 \%$. The FDI share is assumed endogenous. In Brazil, the excluded instruments are industry-region averages of export shares and foreign capital ownership, and industry tariff and import penetration rates. In China, the excluded instruments are industry-region averages of foreign capital ownership, government capital ownership and the fraction of firms that have been restructured into shareholding companies. * represents significance at $10 \%$; ** significance at 5\%; *** significance at $1 \%$. (a) p. value of test of significance of residual(s) of first stage regression(s) in original model. (b) p. value of test of joint significance of excluded instruments in first stage regression. (c) p. value of Hansen $\mathbf{J}$ test of overidentifying restrictions. 